medRxiv preprint doi: https://doi.org/10.1101/2021.07.07.21259278; this version posted July 7, 2021. The copyright holder for this preprint (which was not certified by peer review) is the author/funder, who has granted medRxiv a license to display the preprint in perpetuity.

\title{
Missense variants affecting the actin-binding domains of PLS3 cause X-linked congenital diaphragmatic hernia and body wall defects
}

Florence Petit ${ }^{1,2^{*}}$, Mauro Longoni ${ }^{3,4^{*}}$, Julie Wells ${ }^{5}$, Richard Maser ${ }^{6}$, Matthew J. Dysart ${ }^{3}$, Hannah T.M. Contreras $^{3}$, Frederic Frénois ${ }^{2}$, Eric Bogenschutz ${ }^{5}$, Barbara R. Pober ${ }^{6}$, Robin D. Clark ${ }^{7}$, Philip F. Giampietro $^{8}$, Hilger H. Ropers ${ }^{9}$, Hao Hu${ }^{9}$, Maria Loscertales ${ }^{3,4}$, Xingbin $\mathrm{Ai}^{6}$, Harrison Brand ${ }^{10}$, AnneSophie Jourdain ${ }^{2}$, Marie-Ange Delrue ${ }^{11}$, Brigitte Gilbert-Dussardier ${ }^{12}$, Louise Devisme ${ }^{13}$, Boris Keren ${ }^{14}$, David J. McCulley ${ }^{15}$, Lu Qiao ${ }^{16}$, Rebecca Hernan ${ }^{165}$, Julia Wynn ${ }^{16}$, Tiana M. Scott ${ }^{17}$, Daniel G. Calame $^{18,19,20}$, Zeynep Coban-Akdemir ${ }^{18,21}$, Patricia Hernandez ${ }^{22}$, Andres Hernandez-Garcia ${ }^{18}$, Hagith Yonath $^{23}$, James R. Lupski $i^{18,20,24,25}$, Yufeng Shen 26 , Wendy K. Chung ${ }^{16,27}$, Daryl A. Scott ${ }^{18,20,28}$, Carol J. Bult $^{5}$, Patricia K. Donahoe ${ }^{3,4}$, Frances A. High ${ }^{3,6,29, \%}$

1) Clinique de Génétique, CHU Lille, France

2) EA7364 RADEME, Université de Lille, France

3) Pediatric Surgical Research Laboratories, Massachusetts General Hospital, Boston, MA, USA;

4) Department of Surgery, Harvard Medical School, Boston, MA, USA;

5) The Jackson Laboratory, Bar Harbor, ME, USA

6) Division of Genetics, Department of Pediatrics, Massachusetts General Hospital, Boston, MA, USA;

7) Loma Linda University School of Medicine, Loma Linda, CA, USA;

8) Rutgers Robert Wood Johnson School of Medicine, New Brunswick, NJ 08901;

9) Max Planck Institute for Molecular Genetics, Berlin, Germany;

10) Department of Neurology, Harvard Medical School, Boston, MA, USA

11) Service de Génétique, CHU Bordeaux, France;

12) Service de Génétique, CHU Poitiers, EA3808, Université de Poitiers, France;

13) Institut de Pathologie, CHU Lille, France;

14) Département de Génétique, Hôpital Pitié Salpétrière, CHU Paris, France;

115) Department of Pediatrics, University of San Diego, San Diego, CA, USA

16) Department of Pediatrics, Columbia University, New York, NY USA

17) Department of Microbiology and Molecular Biology, College of Life Sciences, Brigham Young University, Provo, UT, 84602, USA

18) Department of Molecular and Human Genetics, Baylor College of Medicine, Houston, TX, 77030, USA

19) Division of Neurology and Developmental Neuroscience, Department of Pediatrics, Baylor College of Medicine, Houston, TX 77030, USA

20) Texas Children's Hospital, Houston, TX 77030, USA

21) Human Genetics Center, Department of Epidemiology, Human Genetics, and Environmental Sciences, School of Public Health, The University of Texas Health Science Center at Houston, Houston, Texas, USA

22) IDDRC/TCC, Molecular and Human Genetics, Baylor College of Medicine, Houston, TX 77030

23) Internal Medicine A and Genetics Institute, Sheba Medical Center and Sackler School of Medicine,

Tel Aviv University, Tel Aviv, Israel

24) Human Genome Sequencing Center, Baylor College of Medicine, Houston, TX, 77030, USA

25) Department of Pediatrics, Baylor College of Medicine, Houston, TX, 77030, USA

26) Department of Systems Biology, Columbia University, New York, NY USA

27) Department of Medicine, Columbia University, New York, NY USA

28) Department of Molecular Physiology and Biophysics, Baylor College of Medicine, Houston, TX, 77030, USA

29) Department of Surgery, Boston Children's Hospital, MA, USA

${ }^{*}$ Equal contributions

${ }^{\%}$ Corresponding author

NOTE: This preprint reports new research that has not been certified by peer review and should not be used to guide clinical practice. 
medRxiv preprint doi: https://doi.org/10.1101/2021.07.07.21259278; this version posted July 7, 2021. The copyright holder for this preprint (which was not certified by peer review) is the author/funder, who has granted medRxiv a license to display the preprint in perpetuity.

All rights reserved. No reuse allowed without permission.

\section{"Equal contributions}

${ }^{\%}$ Corresponding author

Keywords: PLS3, plastin, fimbrin, actin-binding protein, congenital diaphragmatic hernia, X-linked 
medRxiv preprint doi: https://doi.org/10.1101/2021.07.07.21259278; this version posted July 7, 2021. The copyright holder for this preprint (which was not certified by peer review) is the author/funder, who has granted medRxiv a license to display the preprint in perpetuity.

All rights reserved. No reuse allowed without permission.

\section{ABSTRACT}

Congenital diaphragmatic hernia $(\mathrm{CDH})$ is a relatively common and genetically heterogeneous structural birth defect associated with high mortality and morbidity. We describe eight unrelated families with a novel X-linked condition characterized by diaphragm defects, variable anterior body wall anomalies, and/or facial dysmorphism. Using linkage analysis and whole exome or whole genome sequencing, we identified novel missense variants in the actin binding domains of plastin 3 (PLS3), a gene encoding an actin bundling protein, that co-segregate with disease in all families. Loss-of-function variants in PLS3 have been described previously in association with X-linked osteoporosis. To address these seemingly disparate clinical phenotypes, we performed in silico protein modeling and cellular overexpression experiments, which suggest that the affected residues in individuals with $\mathrm{CDH}$ are important for actin binding and result in disorganization of the actin cytoskeleton and a reduction in normal actin stress fiber formation. A mouse knock-in model of a variant identified in one of the families, p.W499C, shows partial perinatal lethality and recapitulates the key findings of the human phenotype, including diaphragm and abdominal wall defects. Both the mouse model and one surviving adult patient with a PLS3 variant were observed to have increased, rather than decreased, bone mineral density. Together, these clinical and functional data in human and mouse reveal that specific missense variants affecting the actin binding domains of PLS3 may have a gain-of-function effect and cause a new Mendelian disorder.

\section{INTRODUCTION}

Congenital diaphragmatic hernia $(C D H)$ is a common structural birth defect, occurring in 1:3,000 live births in the United States. Anatomically, $\mathrm{CDH}$ is characterized by incomplete formation or muscularization of the developing diaphragm, the most important respiratory muscle, together with lung hypoplasia. It is a severe birth defect, with estimated survival rates of $50-80 \%$, despite advanced medical and surgical care. The most frequent and severe clinical complication is neonatal respiratory distress and hypertension of the pulmonary circulation, both of which can be refractory to standard treatments. Symptomatic infants with $\mathrm{CDH}$ require surgical intervention and often require extended stays in neonatal intensive care units and multiple invasive procedures including the use of extracorporeal membrane oxygenation. Among survivors, respiratory complications, neurodevelopmental deficits, and feeding difficulties requiring life-long medical attention are common ${ }^{1}$.

The genetic causes of $\mathrm{CDH}$, like other structural birth defects, are highly heterogeneous ${ }^{12}$. The most frequently identified genetic causes of sporadic $\mathrm{CDH}$ are recurrent chromosome abnormalities ${ }^{12,34}$ and deleterious de novo single gene variants ${ }^{5,67}$ Familial $\mathrm{CDH}$ is thought to be rare because of the historically high morbidity and mortality in affected individuals, especially in syndromic forms, that impact reproductive fitness. However, studies of rare familial clusters have revealed important human $\mathrm{CDH}$ genes $^{8,9}{ }^{10}$. Several lines of evidence suggest $\mathrm{X}$-linked loci for $\mathrm{CDH}$ : kindreds showing a pattern 
medRxiv preprint doi: https://doi.org/10.1101/2021.07.07.21259278; this version posted July 7, 2021. The copyright holder for this preprint (which was not certified by peer review) is the author/funder, who has granted medRxiv a license to display the preprint in perpetuity.

All rights reserved. No reuse allowed without permission.

consistent with X-linked inheritance, a slightly increased M:F ratio among affected patients ${ }^{11,12}$, and the occurrence of diaphragmatic defects in several X-linked syndromic conditions ${ }^{12}$.

In this report, we describe eight unrelated families with novel variants in the X-linked gene PLS3. The families, including five families with multiple affected individuals, show transmission of congenital diaphragm defects compatible with X-linked inheritance. Sequencing studies identified inherited or de novo missense variants in PLS3 that segregate with affected status in all eight families. PLS3 maps to Xq23 and encodes plastin 3 (also known as T-plastin), an actin-bundling protein. Loss of function (LOF) alleles and deletions in PLS3 have been reported previously in families with X-linked osteoporosis and osteoporotic fractures (MIM\# 300910). Affected males present with childhood osteoporosis and fractures of the axial and appendicular skeleton, while the bone phenotype in affected females ranges from normal bone density to early-onset osteoporosis ${ }^{13}$.

The actin cytoskeleton is a dynamic network that is important for multiple cellular processes in eukaryotes. Actin structures have distinct intracellular localization and are bound to different actin crosslinking proteins, among which are actin-bundling proteins of the plastin family ${ }^{14,15}$. PLS3 encodes one of the three vertebrate Plastin proteins, which bundle together adjacent actin filaments in a calciumresponsive manner. Plastin proteins contain an $\mathrm{N}$-terminal calcium-binding region and two $\mathrm{C}$-terminal actin binding domains that are each comprised of two calponin homology domains. Each actin binding domain binds to adjacent actin filaments, thereby linking them into bundles ${ }^{16}$. These tight actin bundles are critical for formation of specialized actin structures such as stress fibers, filopodia, lamellipodia, and microvilli ${ }^{15}$.

The CDH-associated PLS3 variants all affect residues in the actin binding domains of the protein. These variants are predicted to alter actin binding without causing major conformational changes in the protein in silico, and result in abnormal actin structures in a cell culture model. We also generated a mouse model carrying a humanized sequence for one of the variants observed in patients in our study (p.W499C) that showed variable perinatal lethality, diaphragm and abdominal wall defects, and increased bone mineral density. These data support a novel pathophysiologic mechanism leading to $\mathrm{CDH}$ and/or anterior body wall anomalies with nearly complete penetrance in male probands and variable expressivity in female carriers.

\section{MATERIAL AND METHODS}

Patient recruitment: The study participants were recruited and provided written informed consent according to clinical investigation standards of the Partners/Mass General Brigham Human Research Committee, Boston Children's Hospital Institutional Review Board, Columbia University Irving Medical Center (CUIMC) Institutional Review Board (IRB), and the Baylor College of Medicine Institutional Review Board. All IRB protocols were approved. Written informed consent was obtained from all study participants in accordance with the local IRB protocol and specific consent for photography was obtained 
medRxiv preprint doi: https://doi.org/10.1101/2021.07.07.21259278; this version posted July 7, 2021. The copyright holder for this preprint (which was not certified by peer review) is the author/funder, who has granted medRxiv a license to display the preprint in perpetuity.

All rights reserved. No reuse allowed without permission.

where applicable. Collaboration between investigators was aided by the GeneMatcher community ${ }^{17}$. Clinical and research microarrays were performed on probands and excluded causative copy number variants in affected individuals (data not shown). Detailed clinical data collection was performed by chart review and, where possible, physical examination by members of the study staff.

DNA extraction: DNA was extracted from peripheral blood samples in EDTA using the DNeasy Blood \& Tissue Kit (Qiagen) according to the accompanying handbook. Formalin-fixed and paraffin-embedded (FFPE) tissue was processed with QIAamp DNA FFPE Tissue Kit (Qiagen). Extracted DNA was quantitated with the Quant-iT PicoGreen dsDNA Assay Kit (Thermo Fisher Scientific).

Linkage analysis: Single nucleotide polymorphism (SNP)-data were collected on members of family 1 using the Infinium HumanOmniExpress-24 v1.0 (Illumina) platform. Parametric linkage analysis for Xlinked traits was carried out using MINX in the Merlin software package ${ }^{18}{ }^{18}$, assuming a disease allele with frequency 0.0001 in our model.

\section{Next-generation sequencing:}

Whole exome sequencing (WES) for families 2-4 was performed at the University of Washington Department of Genome Sciences as described previously ${ }^{6}$. WES for families 7 and 8 were performed at Baylor College of Medicine Human Genome Sequencing Center using an Illumina dual indexed, pairedend pre-capture library per manufacturer protocol with modifications (https://www.hgsc.bcm.edu/content/protocols-sequencing-library-construction). Libraries were pooled and hybridized to the HGSC VCRome 2.1 plus custom Spike-In design according to the manufacturer's protocol (NimbleGen) with minor revisions ${ }^{19}$. Paired-end sequencing was performed with the Illumina NovaSeq6000 platform. The sample achieved $98 \%$ of the targeted exome bases covered to a depth of $20 \mathrm{x}$ or greater and had a sequencing yield of $13.2 \mathrm{~Gb}$. Illumina sequence analysis was performed using the HGSC HgV analysis pipeline which moves data through various analysis tools from the initial sequence generation on the instrument to annotated variant calls (SNPs and intra-read in/dels) ${ }^{20,21}$. In parallel to the exome workflow a SNP Trace panel was generated for a final quality assessment. This included orthogonal confirmation of sample identity and purity using the Error Rate In Sequencing (ERIS) pipeline developed at the BCM-HGSC. Using an "e-GenoTyping" approach, ERIS screens all sequence reads for exact matches to probe sequences defined by the variant and position of interest. $A$ successfully sequenced sample must meet quality control metrics of ERIS SNP array concordance $(>90 \%)$ and ERIS average contamination rate $(<5 \%)$. WGS for families 5 and 6 was processed at the Broad Institute Genomic Services as described previously ${ }^{22}$.

WES and WGS data were processed using GATK Best Practice v4.0. using pipelines described previously ${ }^{6,7,22}$. WES interpretation was performed with Seqr (seqr.broadinstitute.org) and/or GEMINI: 
medRxiv preprint doi: https://doi.org/10.1101/2021.07.07.21259278; this version posted July 7, 2021. The copyright holder for this preprint (which was not certified by peer review) is the author/funder, who has granted medRxiv a license to display the preprint in perpetuity. All rights reserved. No reuse allowed without permission.

Integrative Exploration of Genetic Variation and Genome Annotations ${ }^{23}$. The following filters were used for analysis of both WES and WGS: quality filters $G Q>20, A B>25$, coding variants with predicted moderate to high impact including loss-of-function variants (frameshift, nonsense, essential splice site, inframe indel) and missense variants, allele frequency below $0.01 \%$ in the control population database gnomAD, including any of their subpopulations ${ }^{24}$. All rare missense variants were reviewed individually regardless of algorithm predictions of deleterious effect. All reported variants were visualized manually using Integrative Genome Viewer (IGV; http://software.broadinstitute.org/software/igv) and validated by Sanger sequencing.

Data sharing: WES data from families 2-4 has been deposited into the NIH National Center for Biotechnology Information (NCBI) Database of Genome \& Phenotypes (dbGAP). WES data from families 7 and 8 will be deposited into NHGRI Genomic Data Science Analysis, Visualization, and Informatics Labspace (AnVIL). WGS data for families 5 and 6 will be deposited into the data repository of the NICHD Gabriella Miller Kid's First (GMKF) Program.

Protein modeling: Structural modeling is based on the N-terminal actin-crosslinking domain structure from human plastin 3 obtained by $X$-ray diffraction(1AOA) ${ }^{25}$, on the actin-crosslinking core of Arabidopsis fimbrin (1PXY) by X-ray diffraction ${ }^{26}$, and on the fourth $\mathrm{CH}$ domain from human plastin $3 \mathrm{~T}$-isoform (IWJC) by MNR (PDB ID: 1WJO) [unpublished data by deposition authors: Tomizawa, T., Kigawa, T., Koshiba, S., Inoue, M., Yokoyama, S., RIKEN Structural Genomics/Proteomics Initiative (RSGI)]. Data files can be downloaded from the Protein Data Bank (PDB, www.rcsb.org).

Overexpression of PLS3 variants: Recombinant human PLS3 constructs were generated using the high copy number pRP[Exp]-CMV>HA/hPLS3[NM_005032.6] expression vector under the control of the constitutively active CMV promoter (VectorBuilder Inc (Santa Clara, CA)). A hemoagglutinin (HA) tag was fused to the N-terminus of the PLS3 protein for the purpose of immunofluorescence. In situ mutagenesis was performed with the $Q 5 \AA$ Site-Directed Mutagenesis Kit (New England Biolabs, Ipswich, MA) to introduce patient-specific variants, and the resulting plasmids were transformed into One Shot TOP10 chemically competent E. coli cell (Invitrogen). Mutagenesis primers were designed using the NEBaseChanger v.1.2.8 (nebasechanger.neb.com) (vector map, primer sequences, and amplification conditions are provided as Supplemental Materials). Successful mutagenesis was confirmed by Sanger sequencing. Plasmid purification was performed with the QIAGEN Plasmid Mini Kit for colony screening or with the QIAGEN Plasmid Maxi Plus Kit (QIAGEN Inc., Germantown, MD) for transient transfection experiments. RFL-6 cells (ATCC ${ }^{\circledR}$ CCL-192 ${ }^{\mathrm{TM}}$ ) were cultured in modified Ham's F-12 Medium with $1 \%$ Lglutamine (Corning Inc., Corning, NY), supplemented with 10\% fetal bovine serum and $1 \%$ PenicillinStreptomycin. Plasmid DNA (500 ng) was electroporated into 100,000 cells using the Neon ${ }^{\circledR}$ Transfection System (Invitrogen ${ }^{\mathrm{TM}}$, Carlsbad, CA) with a single $1650 \mathrm{~V}$ and 20 ms pulse. Electroporated cells were 
medRxiv preprint doi: https://doi.org/10.1101/2021.07.07.21259278; this version posted July 7, 2021. The copyright holder for this preprint (which was not certified by peer review) is the author/funder, who has granted medRxiv a license to display the preprint in perpetuity. All rights reserved. No reuse allowed without permission.

plated and maintained in Opti-MEM ${ }^{\mathrm{TM}}$ Reduced Serum Medium for 24 hours on coverslips in a 24-well plate until fixation with $4 \%$ paraformaldehyde and staining. The complete list of antibodies and dyes is provided as Supplemental Materials. Electroporation experiments were conducted at least in triplicate and efficiency monitored via parallel transfection of a green fluorescent protein (GFP) expressing plasmid. Images were collected with a Nikon Eclipse 80i equipped with a Photometrics CoolSNAP DYNO Scientific CCD Camera and the NIS-Elements BR 5.02.01 64-bit softwareri. Quantification of actin stress fibers was performed in quadruplicate for each condition, and for each replicate 61-145 images of randomly selected transfected cells were analyzed. A subjective assessment of normal vs. abnormal (reduced) actin stress fibers in each cell was performed by two independent observers who were blinded to the experimental condition. Data are presented per condition as an average of the percentage of cells across replicates displaying normal actin stress fibers, and statistical significances between conditions were calculated using a two-tailed t test.

Whole mount In situ hybridization: The mouse Pls3 probe was generated using a 734 segment of the mouse transcript that was PCR amplified (PCR Master Mix, Promega, Madison, WI) with one set of exonexon boundary overlapping primers (forward: gagctagcagcgtaggtcg and reverse: catttgcagagcacgatccc). The purified PCR fragment was cloned into the $\mathrm{PCR}^{\mathrm{TM}}$ II-TOPO® TA vector (TOPO® TA Cloning $\AA$ Kit, Dual Promoter) (ThermoFisher, Life Technologies Corporation), and transformed into One Shot $\circledast$ TOP10 Chemically Competent Cells (ThermoFisher, Life Technologies Corporation). Sense and anti-sense Digoxigenin-11-UTP labeled probes (DIG RNA Labeling Mix, Sigma-Aldrich) were synthesized with SP6 and T7 RNA polymerases, respectively. E12.5 mouse embryos were collected in cold phosphate-buffered saline (PBS), fixed over night at $4^{\circ} \mathrm{C}$ with $4 \%$ paraformalehyde in PBS, and washed with PBT (PBS with $0.1 \%$ Tween 20 ) at $4^{\circ} \mathrm{C}$. Whole-mount in situ hybridization was performed as described ${ }^{27}$. Embryos were bleached with $6 \%$ hydrogen peroxide in PBT for 1 hour, treated with $10 \mathrm{ug} / \mathrm{mL}$ Proteinase $\mathrm{K}$ (SigmaAldrich) in PBT for 10 minutes, then incubated in pre-warmed hybridization buffer at $70^{\circ} \mathrm{C}$ for 1 hour. DIGlabelled probe was added to fresh hybridization buffer at a concentration of $1 \mathrm{ug} / \mathrm{mL}$, and dissected embryos were incubated in this buffer at $70^{\circ} \mathrm{C}$ overnight. Embryos were then washed stringently and incubated overnight at $4^{\circ} \mathrm{C}$ in preabsorbed 1:2000 anti-DIG antibody (Roche) with $0.1 \%$ goat serum in TBST. Probe was visualized by incubating dissected embryos for 24-48 hours in BM-Purple (Roche). Embryos were then further dissected to isolate the lung for imaging using a Nikon AZ100 microscope.

PIs3 mouse model generation: All research involving animals complied with protocols approved by the Institutional Animal Care and Use Committees (IACUC) from The Jackson Laboratory and Massachusetts General Hospital. Pls3 mice, containing either the W499C substitution in (PIs3 ${ }^{\text {em1Bult }}$, referred to as $P / s 3^{\text {W499C }}$ ) or a 14 bp deletion (Pls ${ }^{\text {em2Bult }}$, referred to as $\left.P / s 3^{14 b p d e l}\right)$ were created at The Jackson Laboratory. To introduce the Pls3 W499C variant into the mouse genome, S. pyogenes Cas 9 gene editing reagents were designed using the Benchling online software tool (benchling.com) targeting Pls3 tryptophan codon 499 (transcript ID PIs3-201, ENMUST00000033547). Introduction of a C->G variant at 
medRxiv preprint doi: https://doi.org/10.1101/2021.07.07.21259278; this version posted July 7, 2021. The copyright holder for this preprint (which was not certified by peer review) is the author/funder, who has granted medRxiv a license to display the preprint in perpetuity.

All rights reserved. No reuse allowed without permission.

mouse chrX:75793603 (positive strand, GRCm38/mm10) results in a change in codon from tryptophan (TGG) to cysteine (TGC) on the negative strand. A single guide RNA (gRNA) sequence (CCTTGACCTTGGCTGTAGTC) was ordered as an ALT-R crRNA and hybridized with ALT-R tracRNA (IDT, Research Triangle Park, NC). A single-stranded oligonucleotide donor to introduce the W499C variant (variant underlined, 5 '

AATATACTAAGGGTGAATTCCTATATGCATATTACTCTGACGCTTCCATAGCCAATACTGTGCACGAT ACCTTCTCATCAGCTGGCAGACTACAGCCAAGGTCAAGGTAGGGTTGCCATCGTTCAGGT-3') was synthesized as an Extremer by Eurofins (USA). Fertilized mouse embryos were generated by natural mating following superovulation of C57BL/6J females and cultured as described previously ${ }^{28}$. Guide RNA, Cas9 protein (IDT), and donor oligos were introduced into C57BL/6J single cell zygotes by electroporation as described ${ }^{28}$. Manipulated embryos were immediately transferred into pseudopregnant female mice in order to obtain liveborn pups. Pls $3^{W 499 C}$ and $P / s 3^{14 b p d e l}$ mice were obtained from the same electroporation experiment as a consequence of different zygotes utilizing different mechanisms of DNA repair.

Pls3 mice were genotyped by PCR using the primers listed below. DNA was isolated from tissues obtained by either ear notching or tail tipping using the Hot Shot method (Truett GE et al. Biotechniques 2000 Jul:29(1):52-54). Each $20 \mathrm{ml}$ PCR reaction consisted of $1 \mathrm{ml}$ of DNA, $1 \mathrm{ml}$ of each genotyping primer, $4 \mathrm{ml}$ of $5 \mathrm{M}$ betaine (Sigma-Aldrich, St. Louis, MO), $4 \mathrm{ml}$ of $5 \mathrm{X}$ Phusion buffer (New England Biolabs, Beverly, MA), $2 \mathrm{ml}$ of dNTP mix (10 mM each dNTP; Promega, Madison, WI) and $0.2 \mathrm{ml}$ of Phusion DNA polymerase (New England Biolabs, Beverly, MA). Reactions were amplified by 28 cycles of PCR with an annealing temperature of $61^{\circ} \mathrm{C}$ and visualized by electrophoresis on a $1.8 \%$ agarose gel. The wild type and KI PCR products are 608 base pairs (bp) in length while the $14 \mathrm{bp}$ del PCR product is $594 \mathrm{bp}$. The following primers were used: PIs3 9064 5'-AGGGAACTCCATGAGAACATCTG-3'and PIs3 9062 5'-GCTTCTGGAGGAAAGAACTAGATC-3'. For animals from the PIs3 colonies, PCR reactions were purified using MagBio High Prep PCR magnetic beads (Gaithersburg, MD) following manufacturer's protocol and subsequently analyzed by Sanger sequencing using primer 9064 .

\section{Mouse diaphragm dissections}

Mice were collected at E18.5 (embryos) or P0 (neonates), fixed overnight in $4 \%$ PFA at $4^{\circ} \mathrm{C}$, and dissected for gross visualization of the body wall, diaphragm, and lungs. Photographs were taken using a Nikon AZ100 microscope. Diaphragm phenotypes were scored from photographs of E18.5 or P0 diaphragms and the investigator was blinded to the genotypes of the animals during the data collection.

\section{Mouse whole mount staining of the body wall}

Postnatal day 0 pups were euthanized through decapitation, the skin along the spine was cut open, and bodies were fixed overnight in $4 \%$ paraformaldehyde at $4^{\circ} \mathrm{C}$. The fixed bodies were then skinned under a 
medRxiv preprint doi: https://doi.org/10.1101/2021.07.07.21259278; this version posted July 7, 2021. The copyright holder for this preprint (which was not certified by peer review) is the author/funder, who has granted medRxiv a license to display the preprint in perpetuity.

All rights reserved. No reuse allowed without permission.

dissection microscope in 1x PBS. Samples were bleached for 2 hours at room temperature in Dent's Bleach (1:2 30\% $\mathrm{H}_{2} \mathrm{O}_{2}$ :Dent's fix), washed three times in Methanol then stored for 2 weeks in Dent's fix (1:4 DMSO:methanol) at $4^{\circ} \mathrm{C}$. Samples were then washed in PBS, incubated for 1 hour in PBS at $65^{\circ} \mathrm{C}$, blocked for 1 hour in 5\% serum and 20\% DMSO, then incubated in alkaline phosphatase-conjugated mouse lgG1 antibody to My32 (Sigma \#A4335) for 48 hours. Staining was then detected using a 1:1 NTMT:NBT/BCIP Substrate Solution (ThermoFisher \#34042) for 40 minutes at room temperature. Images were taken on a Leica M125 stereo microscope. Distance between stained oblique muscles were measured using Adobe Photoshop. Mean distance between stained oblique muscles were compared using Welch's t test.

\section{Mouse bone densitometry}

Wild type C57BL/6J (The Jackson Laboratory, Bar Harbor, ME stock 000664), Pls $3^{\text {W499C }} \mathrm{KI}$ and Pls ${ }^{14 b p d e l}$ mice were analyzed by dual energy $x$-ray absorptiometry (DEXA) at 3 months of age using an UltraFocus scanner (Faxitron, Tuscon, AZ). For this procedure, mice were weighed and anesthetized with continuous inhalation of isofluorane and four sets of images were acquired at low and high energy. Collected data was analyzed by VisionDXA software (using body minus head protocol) and reported as total body weight (g), total tissue mass $(\mathrm{g})$, lean tissue mass $(\mathrm{g})$, fat mass $(\mathrm{g})$, percentage of body weight as fat, total body area $\left(\mathrm{cm}^{2}\right)$, total bone area $\left(\mathrm{cm}^{2}\right)$, bone mineral content $(\mathrm{g})$ and bone mineral density $\left(\mathrm{g} / \mathrm{cm}^{2}\right)$. Eight wildtype females, 8 wildtype males, $7 \mathrm{Pls} 3^{14 b p d e l / 14 b p d e l}$ homozygous females, $8 \mathrm{Pls} 3^{14 b p d e l}$ hemizygous males, $6 \mathrm{Pls} 3^{\text {W99C/W499C }}$ homozygous females, and $3 \mathrm{Pls} 3^{\text {W499C }}$ hemizygous males were studied.

\section{RESULTS}

\section{Clinical Case Descriptions:}

The families were recruited individually into separate studies at the University of Lille, Boston Children's Hospital and Massachusetts General Hospital CDH genetics study, Diaphragmatic Hernia Research \& Exploration, Advancing Molecular Science (DHREAMS), and Baylor College of Medicine. Collaborations were facilitated through GeneMatcher ${ }^{17}$ and connections between researchers across CDH genetics study cohorts. Pedigrees are shown in Figure 1 and clinical details are provided in Table 1.

Family 1 is a large family including 8 affected males and several more mildly affected females. Most affected males died because of diaphragm defects; however, three affected males survived to adulthood. Additionally, one female family member (F1-II.2) presented with a mild form of CDH that was surgically repaired. All surviving affected males and carrier females were noted to have distinct facial features, which include hypertelorism (Data not shown). Only one affected male from this family did not present with $\mathrm{CDH}$ (F1-III.2) but had an extensive supraumbilical abdominal hernia that was surgically repaired shortly after birth (Data not shown). Supraumbilical hernia was also a frequent finding in carrier females (Data not shown). Among the three males that survived to adulthood, one had no 
medRxiv preprint doi: https://doi.org/10.1101/2021.07.07.21259278; this version posted July 7, 2021. The copyright holder for this preprint (which was not certified by peer review) is the author/funder, who has granted medRxiv a license to display the preprint in perpetuity.

All rights reserved. No reuse allowed without permission.

neurodevelopmental findings, though two of the affected males with $\mathrm{CDH}$ had intellectual disability (F1IV.35 and F1-IV.36). In both cases the possibility that the intellectual disability was related to neonatal hypoxia-ischemia could not be ruled out.

As males with loss-of-function variants in PLS3 have been described to have severe and earlyonset osteoporosis $^{13}$, we investigated bone mineralization in one proband of family 1 (F1-III.2) with dualenergy $x$-ray absorptiometry (DEXA). DEXA measurements on the left hip $(Z$ score $+2, T$ score +1.2$)$ and lumbar vertebrae $(Z$ score $+5.8, T$ score +5.4$)$ showed instead increased bone mineral density in this individual (Figure 2C).

Family 2 is a kindred with two affected males that both died in the neonatal period with severe malformations that included left sided posterior $\mathrm{CDH}$ in one and complete absence of the left hemidiaphragm in the other, plus a large anterior body wall defect in both. The body wall defect consisted of supraumbilical muscle deficiency in both cases, and more extensive clefting of the sternum in individual F2-II.1 (Data not shown). Hypoplasia of the corpus callosum was noted at autopsy in individual II.1 but was absent in II.2. The female carrier (F2-I.2) was born with an umbilical hernia that resolved over time without surgical repair, and then subsequently recurred as an epigastric abdominal wall defect following pregnancy. She did not have the same facial features identified in the adult females in family 1 , and her inter-pupillary distance is just above the mean for individuals of European ancestry. Chromosome Xinactivation studies were performed in a peripheral blood sample from the female using Hpall digestion at a polymorphic locus in the AR gene and showed a normal (random) inactivation pattern.

Family 3 has three affected males, all of whom had left-sided posterolateral diaphragm defects. One affected male (F3-IV.2) underwent additional surgical repair of a ureteral abnormality causing hydronephrosis. Additional anomalies, including body wall defects, or dysmorphic features were not reported in the affected individuals, and neurodevelopmental outcomes for the survivors are not available.

Family 4 has three affected male individuals. Beyond reported surgical repair for $\mathrm{CDH}$, limited phenotypic information is available for the proband (F4-III.3), or for his affected male relatives (F4-III.1 and F4-II.1), who are both deceased. Neurodevelopmental or cognitive concerns were not reported for the proband. The female obligate carriers and are not known to be affected by diaphragmatic defects or any other structural birth defect.

Families 5 and 6 each contain one affected male and were identified by screening WGS and WES data from a cohort of 735 patients with $\mathrm{CDH}$ and their unaffected parents ${ }^{7}$. The proband in Family 5 is a male who presented with right-sided $\mathrm{CDH}$ and outpouching of the right side of the abdominal wall, which was evident from birth. Abdominal ultrasound showed congenital absence of the internal oblique and transversus abdominis muscles (Figure 2B). The proband in Family 6 is a male with a diaphragmatic eventration that required surgical repair, and later re-herniation, and no reported body wall defects. Dysmorphic facial features and significant developmental delays were not noted in either of these probands, and there was also no family history of $\mathrm{CDH}$ or other birth defects. 
medRxiv preprint doi: https://doi.org/10.1101/2021.07.07.21259278; this version posted July 7, 2021. The copyright holder for this preprint (which was not certified by peer review) is the author/funder, who has granted medRxiv a license to display the preprint in perpetuity.

All rights reserved. No reuse allowed without permission.

The male proband in Family 7 (F7-II.2) underwent repair of bilateral ventral diaphragmatic hernias, both covered by a hernia sac. He also had a large skin-covered epigastric abdominal wall defect that was surgically repaired. History was also notable for a membranous ventricular septal defect, atrial septal defect, bilateral hydronephrosis, right undescended testis, right inguinal hernia. Dysmorphisms noted at birth included a prominent forehead, hypertelorism, down-slanting palpebral fissures, a broad flattened nasal bridge, anteverted nares, low set ears, micrognathia, a sacral dimple with a hair tuft, and hypoplastic first toenails bilaterally. There were no neurodevelopmental concerns.

Family 8 is a family with 3 affected males. The proband (F8-II.5) had a left-sided posterolateral $\mathrm{CDH}$ covered by a hernia sac that was surgically repaired, and a neurodevelopmental disorder. Other notable findings included a two-vessel umbilical cord, left-sided grade 3 vesicoureteral reflux, intermittent horizontal nystagmus, corneal pannus, and facial dysmorphisms including hypertelorism, down slanting palpebral fissures, low set right ear, short nose with wide nasal root, widely spaced teeth, and a high arched palate. He had delays in speech development and was later diagnosed with autism spectrum disorder and intellectual disability and complex partial seizures. A brain MRI showed enlarged lateral ventricles. The proband had two male relatives who died in infancy from left-sided CDH (F8-II.2 and F8II.3), though samples from these individuals were not available for genetic testing. The family history is also notable for other individuals with neurodevelopmental disorders.

\section{Genetic studies}

Linkage analysis was performed on members of family 1. A logarithm of the odds (LOD) score above 3, indicating positive association with diaphragmatic defects, was obtained for a $3 \mathrm{Mb}$ region on chromosome band Xq23 between chrX:113,889,739-116,906,942 (hg19) (Supplemental Materials). The region includes $P L S 3$, as well as 8 other protein-coding genes and several non-coding transcripts.

Whole exome sequencing (WES) (families 1-4, families 7-8) or whole genome sequencing (WGS) (families 5-6) identified novel missense sequence variants in PLS3 that were either maternally-inherited (7 families) or de novo (in family 7) (Table 2). The PLS3 variants segregated with the diaphragmatic phenotype and were notably absent from unaffected male relatives of probands in the familial cases. All variants were validated by Sanger sequencing. Significant chromosome anomalies and copy number variants were excluded in all probands with clinical or research chromosome microarray analysis. Except for family 8 , no other rare coding candidate variants segregating with the affected individuals were identified. The proband in family 8 carried two additional coding variants of uncertain significance in addition to the PLS3 variant: a non-maternally inherited c.G52C, (p.G18R) variant in SMARCA2, and a maternally inherited c.G133A, (p.G45S) in SYP. A paternal sample was not available for sequencing in this family. SMARCA2 and SYP are both linked with neurodevelopmental phenotypes ${ }^{29,30}$, so it is possible that these variants may be contributing to the neurological features in this individual, which are more severe than in the other patients in this report. However, neither SMARCA2 nor SYP have been linked 
medRxiv preprint doi: https://doi.org/10.1101/2021.07.07.21259278; this version posted July 7, 2021. The copyright holder for this preprint (which was not certified by peer review) is the author/funder, who has granted medRxiv a license to display the preprint in perpetuity.

All rights reserved. No reuse allowed without permission.

with diaphragm or body wall defects, and therefore, in combination with the family history consistent with X-linked inheritance, the PLS3 variant is most likely causative.

All eight $P L S 3$ variants were absent from large population databses (e.g. gnomad $^{24}$ ), altered conserved residues, and are predicted to be pathogenic by in silico algorithms (e.g. CADD ${ }^{31}$ ) (Table 2).

\section{Protein modeling}

We used structural modeling of 3D-interactions of actin-bundling proteins to address the potential effects of the identified missense variants (Figure 3). PLS3 is characterized by an N-terminal headpiece and two C-terminal actin-binding domains (ABD1 and ABD2), formed by tandem pairs of calponinhomology $(\mathrm{CH} 1-\mathrm{CH} 4)$ subdomains ${ }^{16}$. All eight variants identified in families with $\mathrm{CDH}$ are in $\mathrm{ABD} 1$ or $\mathrm{ABD} 2$ and none of them are predicted to cause a conformational change in the protein (Fig 3B). The p.Glu270 and p.Trp499 residues affected in families 1 and 2, respectively, are contained in the core residues involved in actin binding (ABS, acting binding sites) ${ }^{32,33}$. Although the p.Glu270Lys variant (family 1 ) is not predicted to induce conformational changes, it does disrupt the bond between Gly270 and Lys236 (Fig 3B, magenta), which has been shown to be necessary for binding with F-actin ${ }^{25}$. The p.Trp499Cys change (family 2) in the ABD2 domain is predicted to affect the hydrophobic core of the actin-binding site (Fig 3B, yellow). The p.Met592 residue (family 3 ) is also part of the ABD2 domain (Fig $3 \mathrm{~B}$, orange); however, it does not map to any of the characterized actin-binding sites and therefore the consequences of the missense p.Met592Val cannot be inferred by structural modeling alone. The p.Lys364Glu variant (family 4) is predicted to cause loss of the hydrogen bond between Lys364 and the Asp125 residue located in the actin-binding site of ABD1 (Fig 3B, green). The p.Ser120Phe (family 5), p. Iso235Val (family 6), p.Ala206Val (family 7), and p.Phe352Leu (family 8) variants are all located at the actin binding interface of $\mathrm{ABD}$ (Fig 3B) and, given their locations, may alter actin binding.

Structural modeling was also performed on the three missense variants previously linked with osteoporosis $^{34-36}$. The p.Ala368Leu alters the conformation of the ABD1 with a high deviation value (3,325A) (Fig 3C, peach). The p.Leu478Pro variant is predicted to be responsible for major alteration of ABD2 structure since the proline substitution precludes hydrogen bonding with the adjacent amino acid (Fig 3C, pale blue). Finally, the Asn446Ser substitution, also in ABD2, shows the same topology and the same conformation (Fig 3C, pale pink). However, conformation changes can be obscured by the fact that the predicted model is not built with the native structure but with a homologous model having a sequence identity superior to $30 \%$. These findings support a model in which osteoporosis-associated missense variants may be responsible for loss-of-function by major alterations in protein structure, while $\mathrm{CDH}$ associated missense variants do not alter protein conformation but are instead responsible for specific alteration of actin-binding.

\section{PLS3 overexpression studies}


medRxiv preprint doi: https://doi.org/10.1101/2021.07.07.21259278; this version posted July 7, 2021. The copyright holder for this preprint (which was not certified by peer review) is the author/funder, who has granted medRxiv a license to display the preprint in perpetuity.

All rights reserved. No reuse allowed without permission.

To study the functional effect of a subset of $\mathrm{CDH}$-associated PLS3 variants on the actin cytoskeleton, we performed overexpression experiments of wild type and variant PLS3 in RFL-6 cells, which are derived from rat embryonic lung mesenchyme and express very low levels of endogenous PIs3 (data not shown). N-terminal HA-tagged human wild type and mutant PLS3 constructs were electroporated into RFL-6 cells. Immunofluorescent staining of the HA-tagged PLS3 proteins revealed that all variants are translated and co-localize with phalloidin-stained F-actin in the cellular subcortical region, lamellipodia, and filopodia (Figure 4A). Cells overexpressing all CDH-associated HA-PLS3 variants displayed grossly abnormal morphology compared to cells expressing wild type HA-PLS3, with increased microspikes in the lamellipodia and occasional abnormally long filopodia, as well as frequent abnormal intracellular aggregates of actin (Figure 4A). Cells overexpressing $\mathrm{N}$-terminal HA-tagged Glu270Lys-PLS3 and Trp499Cys-PLS3 also showed a quantifiable decrease in the formation of actin stress fibers; furthermore, this effect was not seen by overexpressing the osteoporosis-associated missense variant Leu478Pro- $P L S 3^{34}$ (Figure 4B-C). An effect on cell migration was hypothesized but could not be quantified easily using this cell model. These experiments demonstrate that $\mathrm{CDH}$-associated variants in the actin binding domains of PLS3 perturb the actin cytoskeleton, and that these effects differ from those caused by an osteoporosis-associated missense variant.

\section{Mouse model of the PLS3 W499C variant}

We investigated the expression pattern of PIs3 mRNA in mouse embryos during critical times of diaphragm, lung, and body wall development. PLS3 has been described as being expressed almost ubiquitously in adult non-hematopoietic cells with replicative potential ${ }^{37}$. However, in situ hybridizations showed a complex staining pattern in mouse embryos, demonstrating that this gene is regulated in a tissue-specific manner during embryonic development (Fig 5A). At E12.5 and E13.5, Pls3 is expressed in the diaphragm tissue, between liver and heart, as well as the lung (Figure 5B,C). Strong staining was observed in the lung mesenchyme at E13.5 (Fig 5D). PLS3 protein expression was also present in the mesenchyme and alveolar septae of human neonatal lung specimens (Supplemental Materials). Finally, we detected strong expression in lateral paired and symmetric structures representing the growing edges of the body wall in mouse (Fig 5B), pertinent to the body wall defects seen in some patients.

To model the effect of one human $\mathrm{CDH}$-associated variant in vivo, we generated a knock-in mouse model, $P / s 3^{\text {W499C }}$, carrying the W499C variant observed in Family 2. Another line, Pls3 ${ }^{14 b p d e l}$, which is predicted to cause a frameshift, was also generated from the same germline targeting experiment (Fig 5E). The Pls $3^{14 b p d e l}$ mice were therefore used as a loss-of-function comparison with the Pls $3^{\text {W499C }}$ mice.

$P / s 3^{W 499 C}$ mice were found at expected genotype ratios at late gestation, but there was a significant reduction in the number of hemizygous males and homozygous females that survived to weaning, and most affected pups died within the first 2 days after birth. In contrast, the Pls $3^{14 b p d e l}$ mice were viable and fertile, consistent with another published Pls3 knock-out mode ${ }^{38}$. The $P / s 3^{W 499 C}$ mutants displayed several phenotypes at late gestation and neonatal time points, including diaphragm abnormalities and 
medRxiv preprint doi: https://doi.org/10.1101/2021.07.07.21259278; this version posted July 7, 2021. The copyright holder for this preprint (which was not certified by peer review) is the author/funder, who has granted medRxiv a license to display the preprint in perpetuity.

All rights reserved. No reuse allowed without permission.

anterior body wall defects, both with variable penetrance. The diaphragm defects included thinning of the muscular diaphragm, particularly at the posterolateral edge and the anterior region below the sternum. Less common complete holes in the diaphragm were also observed (Fig 5G-I, Table 3). The abdominal wall defects included midline protrusion of the intestine into a sac at the site of the umbilicus, similar to omphalocele, in a subset of mutant animals (Fig 5J). All the mutants showed thinning of the abdominal wall muscles with widening of the space between the external oblique muscles (Fig 5K-M). Neither diaphragm nor abdominal wall defects were observed in the $P / s 3^{14 b p d e l}$ mice (Table 3, data not shown). We also examined the lungs from $P / s 3^{W 499 C}$ mice, as primary defects of the lung mesenchyme are believed to be linked to $\mathrm{CDH}$-associated pulmonary hypoplasia ${ }^{39,40}$, but we did not observe and major defects in lung structure or cellular markers (supplemental data).

To determine the effect of the W499C variant on bone density, we performed DEXA scans on surviving homozygous female and hemizygous male knock-in mice at 3 months of age (Fig $5 \mathrm{~N}$ ). Compared with age- and sex-matched wildtype control mice, the Pls $3^{W 499 C}$ knock-in mice showed increased bone mineral density. In contrast, the loss-of-function Pls $3^{14 b p d e l}$ mice showed decreased bone mineral density compared to controls (Fig $3 \mathrm{~N}$ ).

\section{DISCUSSION}

The human and mouse data in this study show that missense variants in the actin binding domains of PLS3 are associated with a congenital disorder characterized by diaphragm defects and variable anterior body wall defects, for which we propose the name "PLS3-associated congenital anomaly syndrome". Affected individuals in three families also showed dysmorphic facial features, with hypertelorism being a common finding. It is therefore possible that this syndrome contains a distinctive facial gestalt, though this will require additional investigation as detailed dysmorphology examinations were not available for the other patients. Neurodevelopmental features were notably absent from most of the surviving individuals, except for two adult males in family 1 and the surviving proband in family 8 . In these cases, additional environmental or genetic factors contributing to the neurodevelopmental phenotype could not be ruled out.

The co-occurrence of diaphragm and ventral body wall defects is reminiscent of a pattern of malformation affecting the embryonic midline that has been recognized since the 1950's, described by others as Pentalogy of Cantrell ${ }^{41}$ and thoracoabdominal syndrome (TAS) ${ }^{42,43}$. We identified some commonalities and differences between PLS3-associated congenital anomaly syndrome and these malformation syndromes. Several minor features of TAS, including cardiac defects, cystic hygroma, and hydronephrosis, were each seen in a minority of the individuals we describe with PLS3 variants. The diaphragm defects in the patients with PLS3 variants are predominantly posterolateral, which differ from the ventral diaphragm defects described in most cases of Pentalogy of Cantrell and TAS. While Pentalogy of Cantrell is typically sporadic, TAS has been reported in families consistent with X-linked inheritance ${ }^{42,43}$. Linkage studies in one family mapped a candidate locus to a different region of the $X$ 
medRxiv preprint doi: https://doi.org/10.1101/2021.07.07.21259278; this version posted July 7, 2021. The copyright holder for this preprint (which was not certified by peer review) is the author/funder, who has granted medRxiv a license to display the preprint in perpetuity. All rights reserved. No reuse allowed without permission.

chromosome (Xq27) that does not contain the PLS3 gene ${ }^{44}$. It is therefore likely that variants in several different genes can result in overlapping patterns of malformations.

The Plastin family of actin bundling proteins have been shown to play multiple diverse cellular roles, including regulation of cell shape, motility, adhesion, endocytosis, vesicle trafficking, and organization of specialized cellular structures such as microvilli. The tissue-specific developmental expression pattern of Pls3 is consistent with a role for this gene in the congenital anomalies observed in the patients in this study. Development of the diaphragm requires complex cellular processes including migration and differentiation of the pleuroperitoneal folds, which form the diaphragm's connective tissue and central tendon, as well as skeletal muscle precursors derived from the somites ${ }^{45,46}$. Similarly, cell migration processes are likely critical for development of the abdominal wall ${ }^{47}$. Plastin 3 has been hypothesized to be particularly important for promoting the migration of cells across gaps in the extracellular matrix by stabilizing cellular membrane protrusions ${ }^{48}$. Further research into the effects of actin binding domain variants on cellular processes during development should shed additional insight into the mechanism of the congenital anomalies seen in these patients.

Loss-of-function variants in PLS3 have been described in multiple families to cause X-linked osteoporosis and osteoporotic fractures (MIM\# 300910) (Supplemental Materials) ${ }^{13}$. Loss-of-function of $P / s 3$ in mouse also recapitulates the human osteoporosis phenotype ${ }^{38}$. Nearly all osteoporosis-related human variants in PLS3 result in protein truncation or abnormal splicing, and the few missense and inframe insertion variants in this disorder render the protein either hyporesponsive or hyperresponsive to calcium or completely disrupt actin binding ability in vitro ${ }^{49}$. Therefore, loss-of-function or abnormal calcium responsiveness of PLS3 are the major mechanism in osteoporosis, and the results of our in silico modeling for three missense osteoporosis variants are consistent with this. In contrast, our data support a model that $\mathrm{CDH}$-associated PLS3 variants perturb actin binding and actin cytoskeletal dynamics without causing a major change in protein structure. We hypothesize that these specific cellular functions of PLS3 underly the anomalies seen in the patients.

The observation of increased bone mineral density in the $P / s 3^{W 499 C}$ knock-in mouse model and a patient from family 1 suggests that these variants may have a gain-of-function effect, at least in bone. A gain-of-function model is also supported by data on the homologous yeast protein, fimbrin, encoded by the SAC6 gene. The yeast sac6 suppressor mutation Trp514Cys (homologous to the p.Trp499Cys variant identified in family 2), results in a stronger interaction with actin compared with wild-type ${ }^{50}$. These yeast data also support the pathogenicity of the human p.Trp499Cys variant, specifically. Overexpression of wildtype Pls3 in mice results in increased bone mineral density but did not result in major congenital anomalies $^{38}$, and approximately $5 \%$ of the human population also over-expresses PLS3 without any apparent clinical consequences ${ }^{13}$. Therefore, abnormal plastin-actin interaction, rather than abnormal stoichiometry, is the most likely explanation for the diaphragm and body wall defects. Additional detailed biochemical experiments will be helpful to quantify the differing effects of these classes of human variants on Pls3 function in actin-bundling and calcium responsiveness. 
medRxiv preprint doi: https://doi.org/10.1101/2021.07.07.21259278; this version posted July 7, 2021. The copyright holder for this preprint (which was not certified by peer review) is the author/funder, who has granted medRxiv a license to display the preprint in perpetuity. All rights reserved. No reuse allowed without permission.

Together, these results show that $\mathrm{CDH}$-associated PLS3 variants cause a distinct syndrome from the loss-of-function variants identified in patients with osteoporosis, and support the hypothesis that these missense variants may be gain-of-function.

\section{Acknowledgements}

The study was funded by grants from the National Institute of Child Health and Human Development (NICHD/NIH, http://www.nichd.nih.gov) 2P01HD068250 (P.K. Donahoe), R01 HD057036 (W. Chung), and RO1 HD098458 (D. Scott), the National Human Genome Research Institute (NHGRI) and the National Heart Lung and Blood Institute (NHBLI) to the Baylor-Hopkins Center for Mendelian Genomics (BHCMG, UM1 HG006542, J.R. Lupski). Sequencing services were partially provided through the RS\&G Service by the Northwest Genomics Center at the University of Washington, Department of Genome Sciences, under U.S. Federal Government contract number HHSN268201100037C from the National Heart, Lung, and Blood Institute (M. Longoni, PI), and from the Gabriella Miller Kids First Pediatric Research Program X01 HL132366, X01 HL136998, and X01 HL140543 (W. Chung, PI).

We are grateful to Eric Liao MD, PhD for important experiments in the zebrafish model and discussion that helped understanding of the different effects of loss-of-function variants in Pls3. Christine Wooley (The Jackson Laboratory Center for Biometric Analysis) performed the DEXA assay on the laboratory mice. 
medRxiv preprint doi: https://doi.org/10.1101/2021.07.07.21259278; this version posted July 7, 2021. The copyright holder for this preprint (which was not certified by peer review) is the author/funder, who has granted medRxiv a license to display the preprint in perpetuity.

TABLE 1: Clinical information for affected individuals

\begin{tabular}{|c|c|c|c|c|c|c|c|c|}
\hline $\begin{array}{l}\text { Patien } \\
\mathrm{t} \#\end{array}$ & $\begin{array}{l}\text { Se } \\
x\end{array}$ & $\begin{array}{l}\text { Diaphrag } \\
\text { m defect } \\
\text { type }\end{array}$ & $\begin{array}{l}\text { Body wall } \\
\text { defect } \\
\text { (N/A: not } \\
\text { assessed) } \\
\end{array}$ & $\begin{array}{l}\text { Dysmorphi } \\
\text { c features } \\
\text { (N/A: not } \\
\text { assessed) }\end{array}$ & $\begin{array}{l}\text { Neurodevelopme } \\
\text { ntal features } \\
\text { (N/A: not } \\
\text { applicable) }\end{array}$ & $\begin{array}{l}\text { Other } \\
\text { features }\end{array}$ & $\begin{array}{l}\text { Alive/ } \\
\text { Deceas } \\
\text { ed }\end{array}$ & $\begin{array}{l}\text { Genoty } \\
\text { pe (+: } \\
\text { positive } \\
\text { for } \\
\text { familial } \\
\text { PLS3 } \\
\text { variant, } \\
\text { NT: not } \\
\text { tested) }\end{array}$ \\
\hline$F 1-I I .2$ & $\mathrm{~F}$ & $\begin{array}{l}\text { CDH } \\
\text { (unspecifie } \\
\text { d) } \\
\end{array}$ & $\mathrm{N} / \mathrm{A}$ & $\mathrm{N} / \mathrm{A}$ & ? & & $\begin{array}{l}\text { Deceas } \\
\text { ed }\end{array}$ & NT \\
\hline F1-III.1 & $\mathrm{F}$ & - & - & $\begin{array}{l}\text { hyperteloris } \\
\mathrm{m}\end{array}$ & none & & Alive & + \\
\hline$F 1-I I I .2$ & M & - & $\begin{array}{l}\text { supraumbili } \\
\text { cal } \\
\text { abdominal } \\
\text { hernia }\end{array}$ & $\begin{array}{l}\text { hyperteloris } \\
\mathrm{m}\end{array}$ & none & $\begin{array}{l}\text { high bone } \\
\text { densitometry }\end{array}$ & Alive & + \\
\hline $\mathrm{F} 1-\mid \mathrm{II} .4$ & $\mathrm{~F}$ & - & 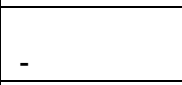 & $\begin{array}{l}\text { hyperteloris } \\
\mathrm{m}\end{array}$ & none & & Alive & + \\
\hline F1-III.9 & M & $\begin{array}{l}\mathrm{CDH} \\
\text { (unspecifie } \\
\text { d) }\end{array}$ & N/A & $N / A$ & N/A & & $\begin{array}{l}\text { Deceas } \\
\text { ed }\end{array}$ & NT \\
\hline $\begin{array}{l}\text { F1- } \\
\text { III.10 }\end{array}$ & $\mathrm{F}$ & $n_{1} \quad y_{1}$ & $\mathrm{~N} / \mathrm{A}$ & $\begin{array}{l}\text { hyperteloris } \\
\mathrm{m}\end{array}$ & none & & Alive & + \\
\hline $\begin{array}{l}\text { F1- } \\
\text { IV.3 }\end{array}$ & $\mathrm{F}$ & - & - & $\begin{array}{l}\text { hyperteloris } \\
\mathrm{m}\end{array}$ & none & & Alive & + \\
\hline $\begin{array}{l}\text { F1- } \\
\text { IV. } 4\end{array}$ & $\mathrm{~F}$ & - & $\begin{array}{l}\text { supraumbili } \\
\text { cal } \\
\text { abdominal } \\
\text { hernia } \\
\end{array}$ & $\begin{array}{l}\text { hyperteloris } \\
\mathrm{m}\end{array}$ & none & & Alive & + \\
\hline $\begin{array}{l}\text { F1- } \\
\text { IV.12 }\end{array}$ & $\mathrm{F}$ & - & $\begin{array}{l}\text { supraumbili } \\
\text { cal } \\
\text { abdominal } \\
\text { hernia }\end{array}$ & $\begin{array}{l}\text { hyperteloris } \\
\mathrm{m}\end{array}$ & none & & Alive & + \\
\hline $\begin{array}{l}\text { F1- } \\
\text { IV.13 }\end{array}$ & M & left $\mathrm{CDH}$ & $\begin{array}{l}\text { omphalocel } \\
\mathrm{e}\end{array}$ & $\mathrm{N} / \mathrm{A}$ & $\mathrm{N} / \mathrm{A}$ & dextrocardia & $\begin{array}{l}\text { Deceas } \\
\text { ed }\end{array}$ & NT \\
\hline $\begin{array}{l}\text { F1- } \\
\text { IV.15 }\end{array}$ & $\mathrm{F}$ & - & - & $\begin{array}{l}\text { hyperteloris } \\
\mathrm{m}\end{array}$ & none & & Alive & + \\
\hline $\begin{array}{l}\text { F1- } \\
\text { IV.16 }\end{array}$ & M & $\begin{array}{l}\text { diaphragm } \\
\text { agenesis }\end{array}$ & - & $\mathrm{N} / \mathrm{A}$ & Neonatal seizures & $\begin{array}{l}\text { bilateral } \\
\text { renal pelvis } \\
\text { dilation }\end{array}$ & $\begin{array}{l}\text { Deceas } \\
\text { ed }\end{array}$ & + \\
\hline $\begin{array}{l}\text { F1- } \\
\text { IV. } 34\end{array}$ & $\mathrm{~F}$ & - & $\mathrm{N} / \mathrm{A}$ & $\begin{array}{l}\text { hyperteloris } \\
\mathrm{m}\end{array}$ & none & & Alive & + \\
\hline $\begin{array}{l}\text { F1- } \\
\text { IV. } 35\end{array}$ & M & $\begin{array}{l}\text { CDH } \\
\text { (unspecifie } \\
\text { d) }\end{array}$ & $\mathrm{N} / \mathrm{A}$ & $\begin{array}{l}\text { hyperteloris } \\
\mathrm{m}\end{array}$ & $\begin{array}{l}\text { intellectual } \\
\text { disability }\end{array}$ & & Alive & NT \\
\hline $\begin{array}{l}\text { F1- } \\
\text { IV.36 }\end{array}$ & M & $\begin{array}{l}\text { CDH } \\
\text { (unspecifie } \\
\text { d) }\end{array}$ & N/A & $\mathrm{N} / \mathrm{A}$ & $\begin{array}{l}\text { intellectual } \\
\text { disability }\end{array}$ & & Alive & NT \\
\hline $\mathrm{F} 1-\mathrm{V} .2$ & $\mathrm{M}$ & $\begin{array}{l}\text { left } \\
\text { diaphragm } \\
\text { agenesis }\end{array}$ & - & $\begin{array}{l}\text { hyperteloris } \\
\mathrm{m}\end{array}$ & Hypotonia & $\begin{array}{l}\text { Left lung } \\
\text { segmentatio } \\
\text { n defect, } \\
\text { bicuspid } \\
\text { aortic valve, } \\
\text { two choroid } \\
\text { cysts }\end{array}$ & $\begin{array}{l}\text { Deceas } \\
\text { ed }\end{array}$ & + \\
\hline
\end{tabular}


medRxiv preprint doi: https://doi.org/10.1101/2021.07.07.21259278; this version posted July 7, 2021. The copyright holder for this preprint (which was not certified by peer review) is the author/funder, who has granted medRxiv a license to display the preprint in perpetuity. All rights reserved. No reuse allowed without permission.

\begin{tabular}{|c|c|c|c|c|c|c|c|c|}
\hline F1-V.6 & M & $\begin{array}{l}\text { left } \\
\text { diaphragm } \\
\text { agenesis }\end{array}$ & $\mathrm{N} / \mathrm{A}$ & $N / A$ & $N / A$ & $\begin{array}{l}\text { Cystic } \\
\text { hygroma, left } \\
\text { lung } \\
\text { segmentatio } \\
\mathrm{n} \text { defect }\end{array}$ & $\begin{array}{l}\text { Deceas } \\
\text { ed }\end{array}$ & + \\
\hline F2-1.2 & $\mathrm{F}$ & - & $\begin{array}{l}\text { umbilical } \\
\text { hernia }\end{array}$ & - & & & Alive & + \\
\hline F2-II.1 & M & $\begin{array}{l}\text { left } \mathrm{CDH} \\
\text { posterolate } \\
\text { ral }\end{array}$ & $\begin{array}{l}\text { supraumbili } \\
\text { cal } \\
\text { abdominal } \\
\text { muscle } \\
\text { deficiency, } \\
\text { cleft } \\
\text { sternum }\end{array}$ & $\mathrm{N} / \mathrm{A}$ & $\mathrm{N} / \mathrm{A}$ & $\begin{array}{l}\text { hypoplasia of } \\
\text { corpus } \\
\text { callosum }\end{array}$ & $\begin{array}{l}\text { Deceas } \\
\text { ed }\end{array}$ & + \\
\hline F2-II.2 & $M$ & $\begin{array}{l}\text { left } \\
\text { diaphragm } \\
\text { agenesis }\end{array}$ & $\begin{array}{l}\text { supraumbili } \\
\text { cal } \\
\text { abdominal } \\
\text { muscle } \\
\text { deficiency }\end{array}$ & $\mathrm{N} / \mathrm{A}$ & $\mathrm{N} / \mathrm{A}$ & & $\begin{array}{l}\text { Deceas } \\
\text { ed }\end{array}$ & + \\
\hline F3-III.3 & M & $\begin{array}{l}\text { left } \mathrm{CDH} \\
\text { posterolate } \\
\text { ral }\end{array}$ & - & - & ? & & Alive & + \\
\hline $\begin{array}{l}\text { F3- } \\
\text { IV.1 }\end{array}$ & $\mathrm{M}$ & $\begin{array}{l}\text { left } \mathrm{CDH} \\
\text { posterolate } \\
\text { ral }\end{array}$ & - & N/A & $N / A$ & & $\begin{array}{l}\text { Deceas } \\
\text { ed }\end{array}$ & + \\
\hline $\begin{array}{l}\text { F3- } \\
\text { IV.2 }\end{array}$ & $\mathrm{M}$ & $\begin{array}{l}\text { left } \mathrm{CDH} \\
\text { posterolate } \\
\text { ral }\end{array}$ & - & - & ? & $\begin{array}{l}\text { Hydronephro } \\
\text { sis with } \\
\text { ureteral } \\
\text { abnormality }\end{array}$ & Alive & + \\
\hline F4-II.1 & $\mathrm{M}$ & $\begin{array}{l}\mathrm{CDH} \\
\text { (unspecifie } \\
\text { d) }\end{array}$ & $\mathrm{N} / \mathrm{A}$ & $\mathrm{N} / \mathrm{A}$ & $\mathrm{N} / \mathrm{A}$ & $\mathrm{N} / \mathrm{A}$ & $\begin{array}{l}\text { Deceas } \\
\text { ed }\end{array}$ & NT \\
\hline F4-III.1 & M & $\begin{array}{l}\text { CDH } \\
\text { (unspecifie } \\
\text { d) }\end{array}$ & $\mathrm{N} / \mathrm{A}$ & $\mathrm{N} / \mathrm{A}$ & $\mathrm{N} / \mathrm{A}$ & $\mathrm{N} / \mathrm{A}$ & $\begin{array}{l}\text { Deceas } \\
\text { ed }\end{array}$ & NT \\
\hline F4-III.3 & M & $\begin{array}{l}\mathrm{CDH} \\
\text { (unspecifie } \\
\text { d) }\end{array}$ & $\mathrm{N} / \mathrm{A}$ & $\mathrm{N} / \mathrm{A}$ & none & $\mathrm{N} / \mathrm{A}$ & Alive & + \\
\hline F5-II.1 & $\mathrm{M}$ & right $\mathrm{CDH}$ & $\begin{array}{l}\text { absence of } \\
\text { right-sided } \\
\text { internal } \\
\text { oblique and } \\
\text { transversus } \\
\text { abdominis } \\
\text { muscles }\end{array}$ & - & none & - & Alive & + \\
\hline F6-II.1 & $M$ & $\begin{array}{l}\text { diaphragm } \\
\text { eventration }\end{array}$ & - & - & none & - & Alive & + \\
\hline
\end{tabular}


medRxiv preprint doi: https://doi.org/10.1101/2021.07.07.21259278; this version posted July 7, 2021. The copyright holder for this preprint (which was not certified by peer review) is the author/funder, who has granted medRxiv a license to display the preprint in perpetuity. All rights reserved. No reuse allowed without permission.

\begin{tabular}{|c|c|c|c|c|c|c|c|c|}
\hline F7-II.2 & $\mathrm{M}$ & $\begin{array}{l}\text { bilateral } \\
\text { ventral } \\
\text { CDH with } \\
\text { hernia } \\
\text { sacs }\end{array}$ & $\begin{array}{l}\text { Epigastric } \\
\text { skin- } \\
\text { covered } \\
\text { abdominal } \\
\text { wall defect }\end{array}$ & $\begin{array}{l}\text { Hyperteloris } \\
\text { m, } \\
\text { prominent } \\
\text { forehead, } \\
\text { broad } \\
\text { flattened } \\
\text { nasal } \\
\text { bridge, } \\
\text { downslantin } \\
\text { g palpepral } \\
\text { fissures, } \\
\text { low set } \\
\text { ears, } \\
\text { Micrognathi } \\
\text { a, } \\
\text { anteverted } \\
\text { nares }\end{array}$ & none & $\begin{array}{l}\text { membranous } \\
\text { ventricular } \\
\text { septal } \\
\text { defect, atrial } \\
\text { septal } \\
\text { defect, } \\
\text { hydronephro } \\
\text { sis, unilateral } \\
\text { cryptorchidis } \\
\text { m, unilateral } \\
\text { inguinal } \\
\text { hernia }\end{array}$ & Alive & + \\
\hline F8-II.2 & $\mathrm{M}$ & $\begin{array}{l}\text { CDH (type } \\
\text { unspecifie } \\
\text { d) }\end{array}$ & $\mathrm{N} / \mathrm{A}$ & $\mathrm{N} / \mathrm{A}$ & $\mathrm{N} / \mathrm{A}$ & $\mathrm{N} / \mathrm{A}$ & $\begin{array}{l}\text { Deceas } \\
\text { ed }\end{array}$ & NT \\
\hline F8-II.3 & $\mathrm{M}$ & $\begin{array}{l}\text { CDH (type } \\
\text { unspecifie } \\
\text { d) }\end{array}$ & $\mathrm{N} / \mathrm{A}$ & $\mathrm{N} / \mathrm{A}$ & $\mathrm{N} / \mathrm{A}$ & $\mathrm{N} / \mathrm{A}$ & $\begin{array}{l}\text { Deceas } \\
\text { ed }\end{array}$ & NT \\
\hline F8-II.5 & $\mathrm{M}$ & $\begin{array}{l}\text { left } \mathrm{CDH} \\
\text { with hernia } \\
\text { sac }\end{array}$ & none & $\begin{array}{l}\text { hyperteloris } \\
\text { m, low set } \\
\text { right ear, } \\
\text { short nose } \\
\text { with wide } \\
\text { nasal root, } \\
\text { downslantin } \\
\text { g palpebral } \\
\text { fissures, } \\
\text { wide } \\
\text { spaced } \\
\text { teeth, high } \\
\text { arched } \\
\text { palate }\end{array}$ & $\begin{array}{l}\text { Intermittent } \\
\text { horizontal } \\
\text { nystagmus, } \\
\text { dilation of lateral } \\
\text { ventricles, speech } \\
\text { delay, Intellectual } \\
\text { disability, autism, } \\
\text { complex partial } \\
\text { seizures }\end{array}$ & $\begin{array}{l}\text { corneal } \\
\text { pannus, } \\
\text { sensory } \\
\text { neural } \\
\text { hearing loss, } \\
\text { malocclusion } \\
\text {, 2 vessel } \\
\text { umbilical } \\
\text { cord }\end{array}$ & Alive & + \\
\hline
\end{tabular}


medRxiv preprint doi: https://doi.org/10.1101/2021.07.07.21259278; this version posted July 7, 2021. The copyright holder for this preprint (which was not certified by peer review) is the author/funder, who has granted medRxiv a license to display the preprint in perpetuity.

All rights reserved. No reuse allowed without permission.

Table 2: CDH-associated PLS3 Variant Details

\begin{tabular}{|c|c|c|c|c|c|}
\hline $\begin{array}{c}\text { Family } \\
\#\end{array}$ & $\begin{array}{c}\text { Variant position } \\
\text { (GRCh38) }\end{array}$ & $\begin{array}{c}\text { Variant } \\
\text { (cDNA)* }^{*}\end{array}$ & $\begin{array}{c}\text { Variant } \\
\text { (protein)* }\end{array}$ & $\begin{array}{c}\text { Alelle } \\
\text { frequency } \\
\text { (gnomAD } \\
\text { v2.1) }\end{array}$ & $\begin{array}{c}\text { CADD } \\
\text { score } \\
\text { (v1.6) }\end{array}$ \\
\hline 1 & ChrX:115636895G>A & c.808G>A & p.E270K & 0 & 31 \\
\hline 2 & ChrX:115646521G>C & c.1497G>C & p.W499C & 0 & 32 \\
\hline 3 & ChrX:115649442A >G & c.1774A>G & p.M592V & 0 & 21.8 \\
\hline 4 & ChrX:115643415A>G & c.1090A>G & p.K364E & 0 & 27.4 \\
\hline 5 & ChrX:115629319 C>T & c.359C>T & p.S120F & 0 & 26.2 \\
\hline 6 & ChrX:115635001A>G & c.703A>G & p.I235V & 0 & 24.8 \\
\hline 7 & ChrX:115634915C>T & c.617C>T & p.A206V & 0 & 25.4 \\
\hline 8 & ChrX:115643379T>C & c.1054T>C & p.F352L & 0 & 27.8 \\
\hline
\end{tabular}

*Variant details are provided for the canonical transcript ENST00000420625.2 
medRxiv preprint doi: https://doi.org/10.1101/2021.07.07.21259278; this version posted July 7, 2021. The copyright holder for this preprint (which was not certified by peer review) is the author/funder, who has granted medRxiv a license to display the preprint in perpetuity.

All rights reserved. No reuse allowed without permission.

Table 3: Summary of diaphragm phenotypes in Pls3 mouse models

\begin{tabular}{|c|c|c|c|c|c|c|}
\hline \multirow[b]{2}{*}{ Genotype } & \multirow[b]{2}{*}{ Sex } & \multirow[b]{2}{*}{$\mathbf{n}$} & \multirow[b]{2}{*}{$\begin{array}{c}\text { Percent } \\
\text { abnormal }\end{array}$} & \multicolumn{3}{|c|}{ Type of Diaphragm Defect } \\
\hline & & & & $\begin{array}{c}\text { Anterior } \\
\text { muscular } \\
\text { thinning }\end{array}$ & $\begin{array}{c}\text { Posterolateral } \\
\text { muscular } \\
\text { thinning }\end{array}$ & $\begin{array}{c}\text { Muscular and } \\
\text { membranous } \\
\text { defect }\end{array}$ \\
\hline Wildtype & M & 5 & $0 \%$ & - & - & - \\
\hline$P / s 3^{\text {W4y9Ci+ }}$ & $\mathrm{F}$ & 6 & $50 \%$ & $3 / 6$ & - & - \\
\hline$P / s 3^{\text {W49yC } / W 49 y C}$ & $\mathrm{~F}$ & 16 & $87.5 \%$ & $14 / 16$ & $6 / 16$ & $1 / 16$ \\
\hline$P / s 3^{\text {W4ygC }}$ & $M$ & 6 & $83.3 \%$ & $5 / 6$ & $3 / 6$ & $1 / 6$ \\
\hline Pls3 ${ }^{14 b p d e l / 14 b p d e l}$ & $\mathrm{~F}$ & 4 & $0 \%$ & - & - & - \\
\hline$P / s 3^{14 b p d e l}$ & $\mathrm{M}$ & 3 & $0 \%$ & - & - & - \\
\hline
\end{tabular}


medRxiv preprint doi: https://doi.org/10.1101/2021.07.07.21259278; this version posted July 7, 2021. The copyright holder for this preprint (which was not certified by peer review) is the author/funder, who has granted medRxiv a license to display the preprint in perpetuity.

All rights reserved. No reuse allowed without permission.

\section{FIGURE 1}

Pedigrees have been removed from the preprint version of the manuscript. Please contact the corresponding author for additional information.

\section{FIGURE 2}

(A) Patient photographs have been removed from preprint version of the manuscript. Please contact the corresponding author for additional information. (B) Ultrasound images demonstrating congenital hypoplasia of the abdominal wall musculature on the right side in the affected male from family 5 (compare arrows showing three normal muscle layers on left and only one muscle layer on right) (C) Bone densitometry performed for an affected adult male from family 1 (F1-III.2). Dual-energy $x$-ray absorptiometry (DXA) measured on left hip and lumbar vertebrae, showing increased bone mineral density.

\section{FIGURE 3}

(A) Locations and types of PLS3 variants in patients with CDH and X-linked osteoporosis. The cDNA structure for the canonical PLS3 transcript ENST00000420625.2 is shown in the top panel and the exons are color-coded depicting the corresponding domains in the Plastin-3 protein, shown in the bottom panel. The $\mathrm{CDH}$ variants are depicted above the CDNA and the osteoporosis variants are depicted below the cDNA. Yellow squares indicate missense variants, and red shapes indicate loss-of-function variants (red square: nonsense, red circle: frameshift, red pentagon: essential splice site, red triangle: in-frame indel). The Plastin-3 protein image shows the following domain types: EF, EF-hand domain; $\mathrm{CH}$, Calponinhomology domain. (B) Predicted protein structures for the actin binding domains of $\mathrm{CDH}$-associated variants. In these images, the predicted structures of each of the eight variant Plastin-3 proteins (multiple colors) are overlaid on the structure of the native (wildtype) Plastin-3 protein (lavender). The amino acid alterations are written in the same color as the corresponding protein structure. The overlaid structures demonstrate that none of the $\mathrm{CDH}$ variants are predicted to cause a major alteration in protein structure. The dotted lines indicate salt bridges between Lys236 and Glu270 (left panel) and Asp125 and Lys364 (middle panel) of the wildtype protein. (C) Predicted protein structures of the actin binding domains of osteoporosis-associated missense variants. The predicted structures of three Plastin-3 variants (peach, pale blue, pale pink) are overlaid on the structure of the native protein (lavender) showing that the osteoporosis variants are predicted to cause a major change in protein structure.

\section{FIGURE 4}

(A) Overexpression of HA-tagged wild-type and variant PLS3 in RFL-6 cells. Green: fluoresceinconjugated phalloidin, staining for filamentous actin. Red: anti-HA antibody, staining for exogenous HAPLS3 protein. Left panel: wild-type PLS3 is distributed homogeneously in RFL-6 embryonic lung fibroblasts (red); actin fibers are normally aligned in the cytoplasm (green). Right panels: mutant PLS3 
medRxiv preprint doi: https://doi.org/10.1101/2021.07.07.21259278; this version posted July 7, 2021. The copyright holder for this preprint (which was not certified by peer review) is the author/funder, who has granted medRxiv a license to display the preprint in perpetuity.

All rights reserved. No reuse allowed without permission.

accumulates on the cell edges where it is strongly associated with F-actin; actin fibers are abnormally positioned, resulting in distorted cell morphology. Additionally, mutant PLS3 is highly expressed in abnormal and increased number of lamellipodia (arrows) and filopodia (arrowheads). (B) Phalloidin staining (white) to visualize actin stress fibers in RFL-6 cells overexpressing wildtype PLS3, two CDHassociated Pls3 variants (Glu270Lys and Trp499Cys) and one osteoporosis-associated PLS3 missense variant (Leu478Pro). (C) The percentage of cells in the experiment depicted in (B) showing normal actin stress fiber formation was quantified in a blinded analysis as described in the methods. ${ }^{*} p$-value $<0.001$.

\section{FIGURE 5}

(A-D) Whole-mount in situ hybridization for Pls3 in mouse embryos at E12.5 (A-C) and E13.5(D). (A) Pls3 mRNA is observed in face, limbs, tail and axial skeleton in a E12.5. (B) The ventral view shows Pls3 in symmetrical structures lateral to the midline (arrow) with a distribution compatible with edges of the anterior body wall. (C) Dissection of the lateral body wall shows that Pls3 mRNA is expressed in the developing lung (arrowhead) but not in the heart $(\mathrm{H})$ or in the liver $(\mathrm{L})$. The developing diaphragm, nested between the heart and the liver, shows Pls3 expression (red arrow in insert). (D) Microdissection of the lung shows Pls3 expression in the lung is specific to the mesenchyme at E13.5. (E-F). (E) Targeting strategy for PIs3W499C knockin and Pls314bpdel mice. The knock-in results in a single amino acid substitution at position 499. The $14 \mathrm{bp}$ deletion results in a deletion and frameshift, with predicted truncation of the protein at 502aa. (F-I) Images of the diaphragms dissected from E18.5 or P0 wildtype and Pls3W499C mutant mice. Abnormalities seen in the mutants include muscular thinning anteriorly under the sternum (arrow in $\mathrm{G}$ ), muscular thinning posterolaterally (arrows in $\mathrm{H}$ ) and complete holes in the diaphragm ( ${ }^{*}$ in I). (J) Omphalocele (arrow) in a Pls3W499C mutant at P0. (K-L) Whole mount myosin staining to visualize the body wall musculature in wildtype and PIs3W499C mutants at P0. Red bars show the distance between the external oblique muscles. (M) Quantification of the distance between the external oblique muscles showing a statistically significant increase in the PIs3W499C knock-in compared to controls. ${ }^{* * * *}$ represents $\mathrm{P}<0.0001$. Error bars on graph represent the standard error of the mean, centered on the mean of each genotype. (O) Bone densitometry studies of 3 month-old Pls314bpdel and PIs3W499C mice compared with age- and sex-matched controls. Bone mineral density values are shown for wildtype females ( $n=8)$, Pls314bpdel homozygous females $(n=7)$, Pls3W499C homozygous females $(n=6)$, wildtype males $(n=8)$, Pls314bpdel hemizygous males $(n=8)$, and Pls3W499C hemizygous males $(n=3)$. P-values compared with sex-matched controls: ${ }^{*}<0.05,{ }^{* *}<0.002,{ }^{* * *}<0.0005$. Error bars indicate one standard deviation of the mean.

\section{References}


medRxiv preprint doi: https://doi.org/10.1101/2021.07.07.21259278; this version posted July 7, 2021. The copyright holder for this preprint (which was not certified by peer review) is the author/funder, who has granted medRxiv a license to display the preprint in perpetuity.

All rights reserved. No reuse allowed without permission.

1. Longoni, M., Pober, B.R., and High, F.A. (1993). Congenital Diaphragmatic Hernia Overview. In GeneReviews((R)), M.P. Adam, H.H. Ardinger, R.A. Pagon, S.E. Wallace, L.J.H. Bean, G. Mirzaa, and A. Amemiya, eds.

2. Yu, L., Hernan, R.R., Wynn, J., and Chung, W.K. (2020). The influence of genetics in congenital diaphragmatic hernia. Semin Perinatol 44, 151169. 10.1053/j.semperi.2019.07.008.

3. Zhu, Q., High, F.A., Zhang, C., Cerveira, E., Russell, M.K., Longoni, M., Joy, M.P., Ryan, M., MilHomens, A., Bellfy, L., et al. (2018). Systematic analysis of copy number variation associated with congenital diaphragmatic hernia. Proc Natl Acad Sci U S A 115, 5247-5252. 10.1073/pnas.1714885115.

4. Yu, L., Wynn, J., Ma, L., Guha, S., Mychaliska, G.B., Crombleholme, T.M., Azarow, K.S., Lim, F.Y., Chung, D.H., Potoka, D., et al. (2012). De novo copy number variants are associated with congenital diaphragmatic hernia. J Med Genet 49, 650-659. 10.1136/jmedgenet-2012-101135.

5. Yu, L., Sawle, A.D., Wynn, J., Aspelund, G., Stolar, C.J., Arkovitz, M.S., Potoka, D., Azarow, K.S., Mychaliska, G.B., Shen, Y., and Chung, W.K. (2015). Increased burden of de novo predicted deleterious variants in complex congenital diaphragmatic hernia. Hum Mol Genet 24, 47644773. $10.1093 / \mathrm{hmg} / \mathrm{ddv} 196$.

6. Longoni, M., High, F.A., Qi, H., Joy, M.P., Hila, R., Coletti, C.M., Wynn, J., Loscertales, M., Shan, L., Bult, C.J., et al. (2017). Genome-wide enrichment of damaging de novo variants in patients with isolated and complex congenital diaphragmatic hernia. Hum Genet 136, 679-691. 10.1007/s00439-017-1774-y.

7. Qi, H., Yu, L., Zhou, X., Wynn, J., Zhao, H., Guo, Y., Zhu, N., Kitaygorodsky, A., Hernan, R., Aspelund, G., et al. (2018). De novo variants in congenital diaphragmatic hernia identify MYRF as a new syndrome and reveal genetic overlaps with other developmental disorders. PLoS Genet 14, e1007822. 10.1371/journal.pgen.1007822.

8. Kantarci, S., Al-Gazali, L., Hill, R.S., Donnai, D., Black, G.C., Bieth, E., Chassaing, N., Lacombe, D., Devriendt, K., Teebi, A., et al. (2007). Mutations in LRP2, which encodes the multiligand receptor megalin, cause Donnai-Barrow and facio-oculo-acoustico-renal syndromes. Nat Genet 39, 957959. 10.1038/ng2063.

9. Yu, L., Wynn, J., Cheung, Y.H., Shen, Y., Mychaliska, G.B., Crombleholme, T.M., Azarow, K.S., Lim, F.Y., Chung, D.H., Potoka, D., et al. (2013). Variants in GATA4 are a rare cause of familial and sporadic congenital diaphragmatic hernia. Hum Genet 132, 285-292. 10.1007/s00439-012-12490 .

10. Longoni, M., Russell, M.K., High, F.A., Darvishi, K., Maalouf, F.I., Kashani, A., Tracy, A.A., Coletti, C.M., Loscertales, M., Lage, K., et al. (2015). Prevalence and penetrance of ZFPM2 mutations and deletions causing congenital diaphragmatic hernia. Clin Genet 87, 362-367. 10.1111/cge.12395.

11. McGivern, M.R., Best, K.E., Rankin, J., Wellesley, D., Greenlees, R., Addor, M.C., Arriola, L., de Walle, H., Barisic, I., Beres, J., et al. (2015). Epidemiology of congenital diaphragmatic hernia in Europe: a register-based study. Arch Dis Child Fetal Neonatal Ed 100, F137-144. 10.1136/archdischild-2014-306174.

12. Shanmugam, H., Brunelli, L., Botto, L.D., Krikov, S., and Feldkamp, M.L. (2017). Epidemiology and Prognosis of Congenital Diaphragmatic Hernia: A Population-Based Cohort Study in Utah. Birth Defects Res 109, 1451-1459. 10.1002/bdr2.1106.

13. van Dijk, F.S., Zillikens, M.C., Micha, D., Riessland, M., Marcelis, C.L., de Die-Smulders, C.E., Milbradt, J., Franken, A.A., Harsevoort, A.J., Lichtenbelt, K.D., et al. (2013). PLS3 mutations in Xlinked osteoporosis with fractures. N Engl J Med 369, 1529-1536. 10.1056/NEJMoa1308223.

14. Delanote, V., Vandekerckhove, J., and Gettemans, J. (2005). Plastins: versatile modulators of actin organization in (patho)physiological cellular processes. Acta Pharmacol Sin 26, 769-779. 10.1111/j.1745-7254.2005.00145.x. 
medRxiv preprint doi: https://doi.org/10.1101/2021.07.07.21259278; this version posted July 7, 2021. The copyright holder for this preprint (which was not certified by peer review) is the author/funder, who has granted medRxiv a license to display the preprint in perpetuity.

All rights reserved. No reuse allowed without permission.

15. Shinomiya, H. (2012). Plastin family of actin-bundling proteins: its functions in leukocytes, neurons, intestines, and cancer. Int J Cell Biol 2012, 213492. 10.1155/2012/213492.

16. Volkmann, N., DeRosier, D., Matsudaira, P., and Hanein, D. (2001). An atomic model of actin filaments cross-linked by fimbrin and its implications for bundle assembly and function. J Cell Biol 153, 947-956. 10.1083/jcb.153.5.947.

17. Sobreira, N., Schiettecatte, F., Valle, D., and Hamosh, A. (2015). GeneMatcher: a matching tool for connecting investigators with an interest in the same gene. Hum Mutat 36, 928-930. 10.1002/humu.22844.

18. Abecasis, G.R., Cherny, S.S., Cookson, W.O., and Cardon, L.R. (2002). Merlin--rapid analysis of dense genetic maps using sparse gene flow trees. Nat Genet 30, 97-101. 10.1038/ng786.

19. Challis, D., Yu, J., Evani, U.S., Jackson, A.R., Paithankar, S., Coarfa, C., Milosavljevic, A., Gibbs, R.A., and Yu, F. (2012). An integrative variant analysis suite for whole exome next-generation sequencing data. BMC Bioinformatics 13, 8. 10.1186/1471-2105-13-8.

20. Reid, J.G., Carroll, A., Veeraraghavan, N., Dahdouli, M., Sundquist, A., English, A., Bainbridge, M., White, S., Salerno, W., Buhay, C., et al. (2014). Launching genomics into the cloud: deployment of Mercury, a next generation sequence analysis pipeline. BMC Bioinformatics 15, 30. 10.1186/1471-2105-15-30.

21. Karaca, E., Harel, T., Pehlivan, D., Jhangiani, S.N., Gambin, T., Coban Akdemir, Z., GonzagaJauregui, C., Erdin, S., Bayram, Y., Campbell, I.M., et al. (2015). Genes that Affect Brain Structure and Function Identified by Rare Variant Analyses of Mendelian Neurologic Disease. Neuron 88, 499-513. 10.1016/j.neuron.2015.09.048.

22. Qiao, L., Wynn, J., Yu, L., Hernan, R., Zhou, X., Duron, V., Aspelund, G., Farkouh-Karoleski, C., Zygumunt, A., Krishnan, U.S., et al. (2020). Likely damaging de novo variants in congenital diaphragmatic hernia patients are associated with worse clinical outcomes. Genet Med 22, 2020-2028. 10.1038/s41436-020-0908-0.

23. Paila, U., Chapman, B.A., Kirchner, R., and Quinlan, A.R. (2013). GEMINI: integrative exploration of genetic variation and genome annotations. PLoS Comput Biol 9, e1003153. 10.1371/journal.pcbi.1003153.

24. Karczewski, K.J., Francioli, L.C., Tiao, G., Cummings, B.B., Alfoldi, J., Wang, Q., Collins, R.L., Laricchia, K.M., Ganna, A., Birnbaum, D.P., et al. (2020). The mutational constraint spectrum quantified from variation in 141,456 humans. Nature 581, 434-443. 10.1038/s41586-020-23087.

25. Goldsmith, S.C., Pokala, N., Matsudaira, P., and Almo, S.C. (1997). Crystallization and preliminary crystallographic analysis of the $\mathrm{N}$-terminal actin binding domain of human fimbrin. Proteins 28 , 452-453. 10.1002/(sici)1097-0134(199707)28:3<452::aid-prot13>3.0.co;2-g.

26. Klein, M.G., Shi, W., Ramagopal, U., Tseng, Y., Wirtz, D., Kovar, D.R., Staiger, C.J., and Almo, S.C. (2004). Structure of the actin crosslinking core of fimbrin. Structure 12, 999-1013. 10.1016/j.str.2004.04.010.

27. Riddle, R.D., Johnson, R.L., Laufer, E., and Tabin, C. (1993). Sonic hedgehog mediates the polarizing activity of the ZPA. Cell 75, 1401-1416. 10.1016/0092-8674(93)90626-2.

28. Qin, W., Dion, S.L., Kutny, P.M., Zhang, Y., Cheng, A.W., Jillette, N.L., Malhotra, A., Geurts, A.M., Chen, Y.G., and Wang, H. (2015). Efficient CRISPR/Cas9-Mediated Genome Editing in Mice by Zygote Electroporation of Nuclease. Genetics 200, 423-430. 10.1534/genetics.115.176594.

29. Cappuccio, G., Sayou, C., Tanno, P.L., Tisserant, E., Bruel, A.L., Kennani, S.E., Sa, J., Low, K.J., Dias, C., Havlovicova, M., et al. (2020). De novo SMARCA2 variants clustered outside the helicase domain cause a new recognizable syndrome with intellectual disability and blepharophimosis distinct from Nicolaides-Baraitser syndrome. Genet Med 22, 1838-1850. 10.1038/s41436-0200898-y. 
medRxiv preprint doi: https://doi.org/10.1101/2021.07.07.21259278; this version posted July 7, 2021. The copyright holder for this preprint (which was not certified by peer review) is the author/funder, who has granted medRxiv a license to display the preprint in perpetuity.

All rights reserved. No reuse allowed without permission.

30. Tarpey, P.S., Smith, R., Pleasance, E., Whibley, A., Edkins, S., Hardy, C., O'Meara, S., Latimer, C., Dicks, E., Menzies, A., et al. (2009). A systematic, large-scale resequencing screen of Xchromosome coding exons in mental retardation. Nat Genet 41, 535-543. 10.1038/ng.367.

31. Rentzsch, P., Schubach, M., Shendure, J., and Kircher, M. (2021). CADD-Splice-improving genome-wide variant effect prediction using deep learning-derived splice scores. Genome Med 13, 31. 10.1186/s13073-021-00835-9.

32. Bresnick, A.R., Janmey, P.A., and Condeelis, J. (1991). Evidence that a 27-residue sequence is the actin-binding site of ABP-120. J Biol Chem 266, 12989-12993.

33. Levine, B.A., Moir, A.J., Patchell, V.B., and Perry, S.V. (1992). Binding sites involved in the interaction of actin with the N-terminal region of dystrophin. FEBS Lett 298, 44-48. 10.1016/0014-5793(92)80019-d.

34. Fahiminiya, S., Majewski, J., Al-Jallad, H., Moffatt, P., Mort, J., Glorieux, F.H., Roschger, P., Klaushofer, K., and Rauch, F. (2014). Osteoporosis caused by mutations in PLS3: clinical and bone tissue characteristics. J Bone Miner Res 29, 1805-1814. 10.1002/jbmr.2208.

35. Kampe, A.J., Costantini, A., Makitie, R.E., Jantti, N., Valta, H., Mayranpaa, M., Kroger, H., Pekkinen, M., Taylan, F., Jiao, H., and Makitie, O. (2017). PLS3 sequencing in childhood-onset primary osteoporosis identifies two novel disease-causing variants. Osteoporos Int 28, 30233032. 10.1007/s00198-017-4150-9.

36. Nishi, E., Masuda, K., Arakawa, M., Kawame, H., Kosho, T., Kitahara, M., Kubota, N., Hidaka, E., Katoh, Y., Shirahige, K., and Izumi, K. (2016). Exome sequencing-based identification of mutations in non-syndromic genes among individuals with apparently syndromic features. Am J Med Genet A 170, 2889-2894. 10.1002/ajmg.a.37826.

37. de Arruda, M.V., Watson, S., Lin, C.S., Leavitt, J., and Matsudaira, P. (1990). Fimbrin is a homologue of the cytoplasmic phosphoprotein plastin and has domains homologous with calmodulin and actin gelation proteins. J Cell Biol 111, 1069-1079. 10.1083/jcb.111.3.1069.

38. Neugebauer, J., Heilig, J., Hosseinibarkooie, S., Ross, B.C., Mendoza-Ferreira, N., Nolte, F., Peters, M., Holker, I., Hupperich, K., Tschanz, T., et al. (2018). Plastin 3 influences bone homeostasis through regulation of osteoclast activity. Hum Mol Genet 27, 4249-4262. $10.1093 / \mathrm{hmg} / \mathrm{ddy} 318$.

39. Keijzer, R., Liu, J., Deimling, J., Tibboel, D., and Post, M. (2000). Dual-hit hypothesis explains pulmonary hypoplasia in the nitrofen model of congenital diaphragmatic hernia. Am J Pathol 156, 1299-1306. 10.1016/S0002-9440(10)65000-6.

40. Donahoe, P.K., Longoni, M., and High, F.A. (2016). Polygenic Causes of Congenital Diaphragmatic Hernia Produce Common Lung Pathologies. Am J Pathol 186, 2532-2543. 10.1016/j.ajpath.2016.07.006.

41. Cantrell, J.R., Haller, J.A., and Ravitch, M.M. (1958). A syndrome of congenital defects involving the abdominal wall, sternum, diaphragm, pericardium, and heart. Surg Gynecol Obstet 107, 602614.

42. Carmi, R., Barbash, A., and Mares, A.J. (1990). The thoracoabdominal syndrome (TAS): a new Xlinked dominant disorder. Am J Med Genet 36, 109-114. 10.1002/ajmg.1320360122.

43. Parvari, R., Weinstein, Y., Ehrlich, S., Steinitz, M., and Carmi, R. (1994). Linkage localization of the thoraco-abdominal syndrome (TAS) gene to Xq25-26. Am J Med Genet 49, 431-434.

10.1002/ajmg.1320490416.

44. Parvari, R., Carmi, R., Weissenbach, J., Pilia, G., Mumm, S., and Weinstein, Y. (1996). Refined genetic mapping of X-linked thoracoabdominal syndrome. Am J Med Genet 61, 401-402. 10.1002/(SICI)1096-8628(19960202)61:4<401::AID-AJMG18>3.0.CO;2-W.

45. Merrell, A.J., and Kardon, G. (2013). Development of the diaphragm -- a skeletal muscle essential for mammalian respiration. FEBS J 280, 4026-4035. 10.1111/febs.12274. 
medRxiv preprint doi: https://doi.org/10.1101/2021.07.07.21259278; this version posted July 7, 2021. The copyright holder for this preprint

(which was not certified by peer review) is the author/funder, who has granted medRxiv a license to display the preprint in perpetuity.

All rights reserved. No reuse allowed without permission.

46. Merrell, A.J., Ellis, B.J., Fox, Z.D., Lawson, J.A., Weiss, J.A., and Kardon, G. (2015). Muscle connective tissue controls development of the diaphragm and is a source of congenital diaphragmatic hernias. Nat Genet 47, 496-504. 10.1038/ng.3250.

47. Khan, F.A., Hashmi, A., and Islam, S. (2019). Insights into embryology and development of omphalocele. Semin Pediatr Surg 28, 80-83. 10.1053/j.sempedsurg.2019.04.003.

48. Garbett, D., Bisaria, A., Yang, C., McCarthy, D.G., Hayer, A., Moerner, W.E., Svitkina, T.M., and Meyer, T. (2020). T-Plastin reinforces membrane protrusions to bridge matrix gaps during cell migration. Nat Commun 11, 4818. 10.1038/s41467-020-18586-3.

49. Schwebach, C.L., Kudryashova, E., Zheng, W., Orchard, M., Smith, H., Runyan, L.A., Egelman, E.H., and Kudryashov, D.S. (2020). Osteogenesis imperfecta mutations in plastin 3 lead to impaired calcium regulation of actin bundling. Bone Res 8, 21. 10.1038/s41413-020-0095-2.

50. Brower, S.M., Honts, J.E., and Adams, A.E. (1995). Genetic analysis of the fimbrin-actin binding interaction in Saccharomyces cerevisiae. Genetics 140, 91-101. 
medRxiv preprint doi: https://doi.org/10.1101/2021.07.07.21259278; this version posted July 7, 2021. The copyright holder for this preprint (which was not certified by peer review) is the author/funder, who has granted medRxiv a license to display the preprint in perpetuity.

All rights reserved. No reuse allowed without permission.

Figure 1

(Pedigrees removed from pre-print version of manuscript) 
medRxiv preprint doi: https://doi.org/10.1101/2021.07.07.21259278; this version posted July 7, 2021. The copyright holder for this preprint (which was not certified by peer review) is the author/funder, who has granted medRxiv a license to display the preprint in perpetuity.

All rights reserved. No reuse allowed without permission.

Figure 2

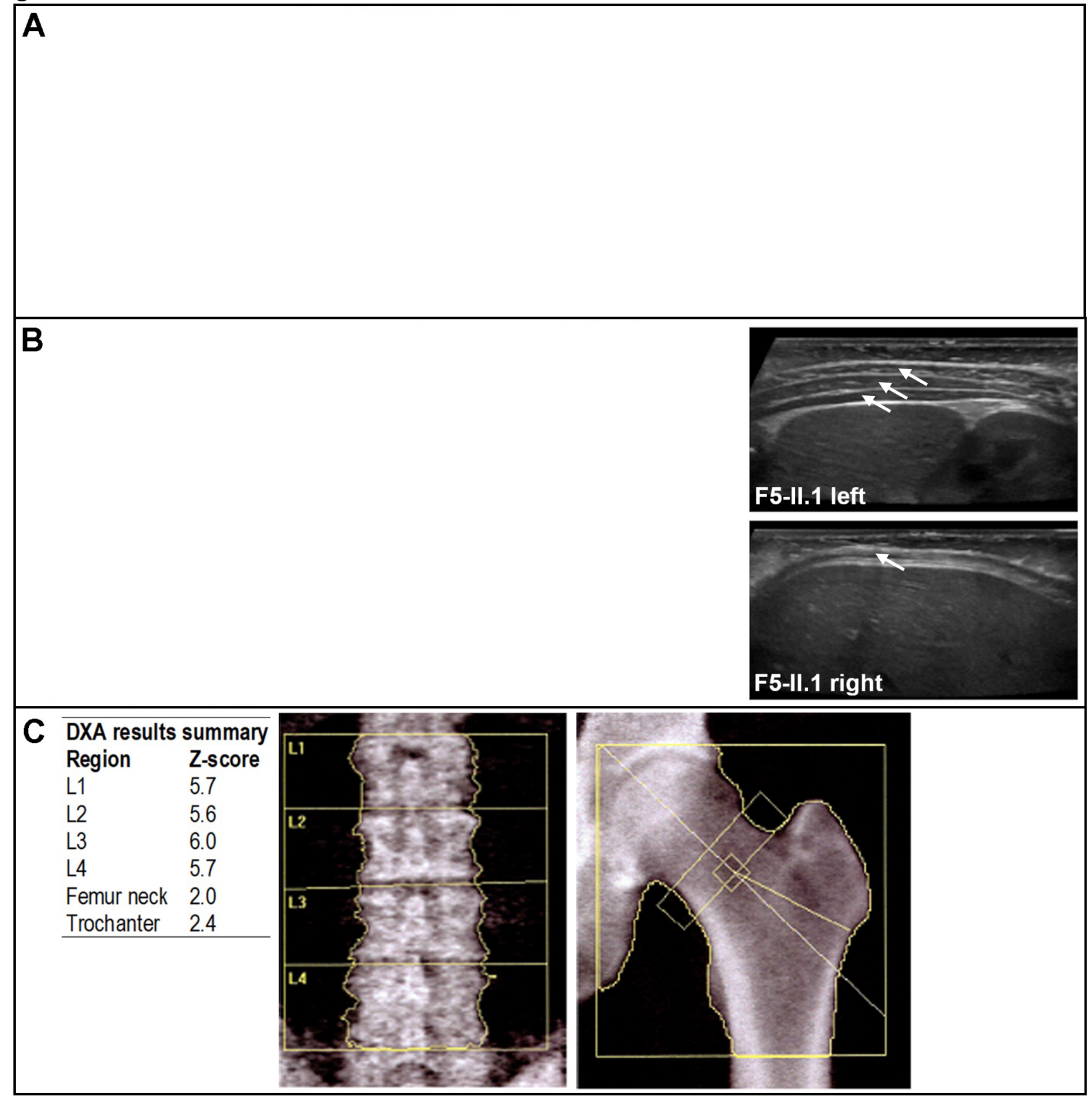


medRxiv preprint doi: https://doi.org/10.1101/2021.07.07.21259278; this version posted July 7, 2021. The copyright holder for this preprint (which was not certified by peer review) is the author/funder, who has granted medRxiv a license to display the preprint in perpetuity.

Figure 3

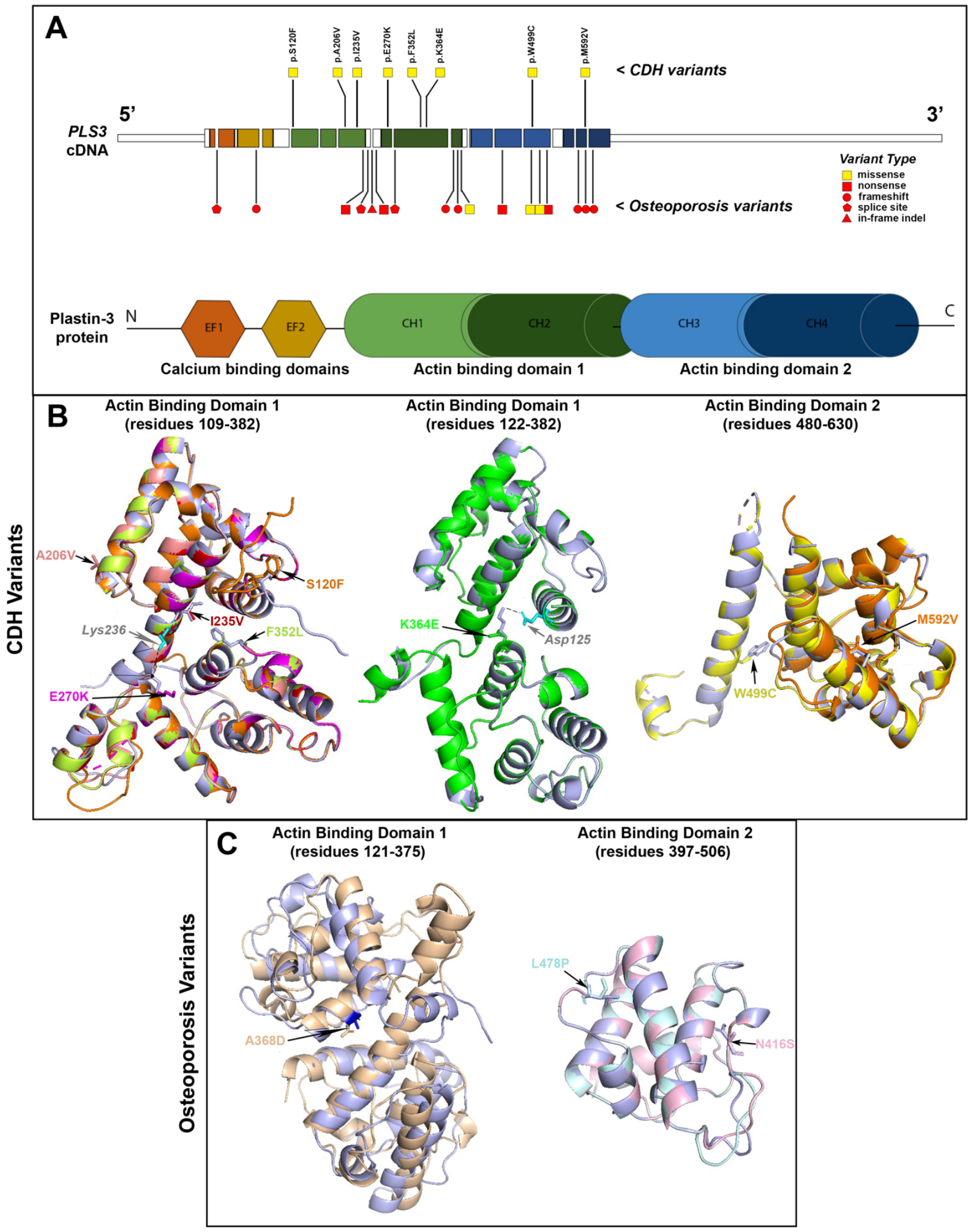


medRxiv preprint doi: https://doi.org/10.1101/2021.07.07.21259278; this version posted July 7, 2021. The copyright holder for this preprint (which was not certified by peer review) is the author/funder, who has granted medRxiv a license to display the preprint in perpetuity.

All rights reserved. No reuse allowed without permission.

Figure 4

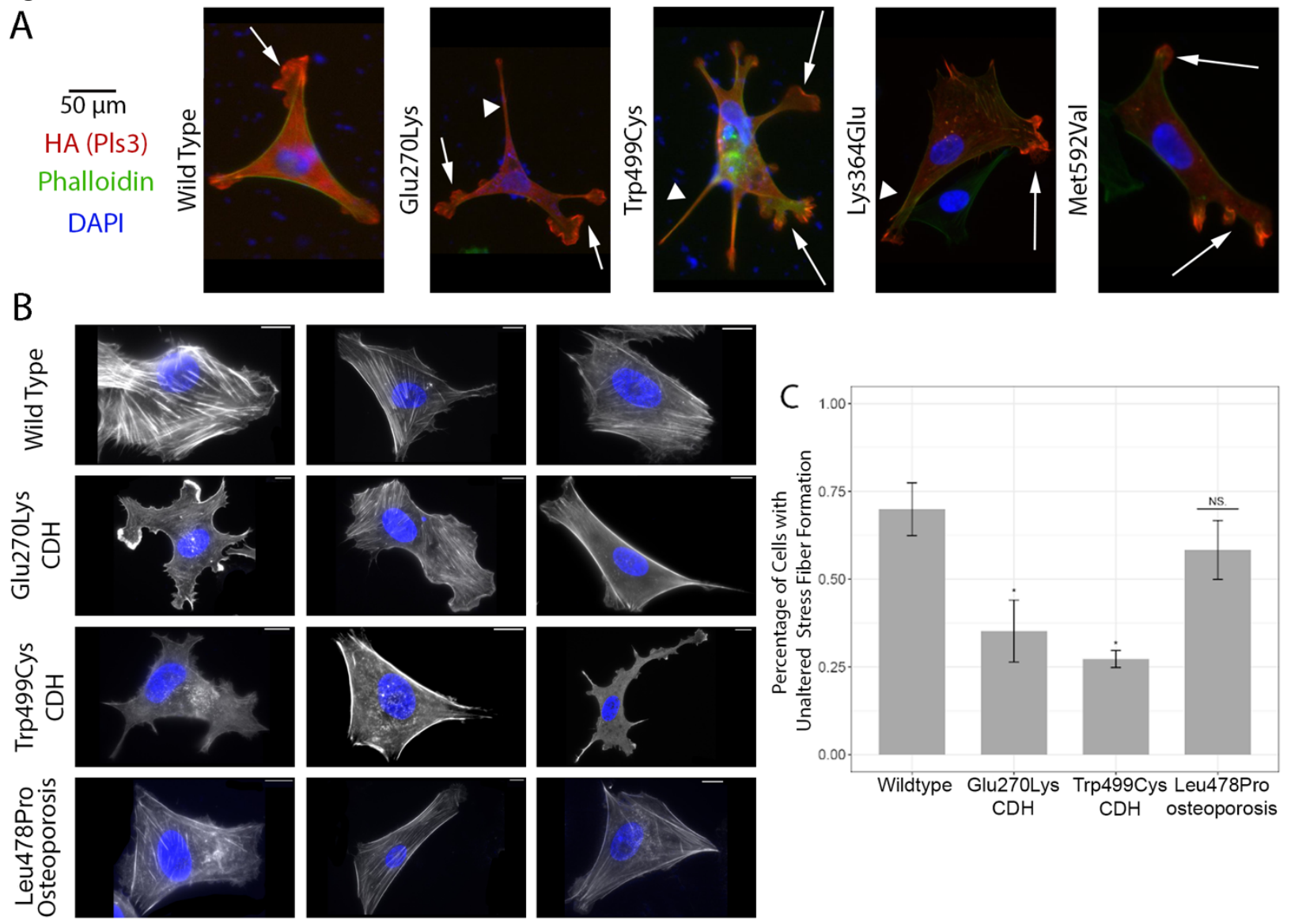


medRxiv preprint doi: https://doi.org/10.1101/2021.07.07.21259278; this version posted July 7, 2021. The copyright holder for this preprint (which was not certified by peer review) is the author/funder, who has granted medRxiv a license to display the preprint in perpetuity.

All rights reserved. No reuse allowed without permission.

\section{Figure 5}
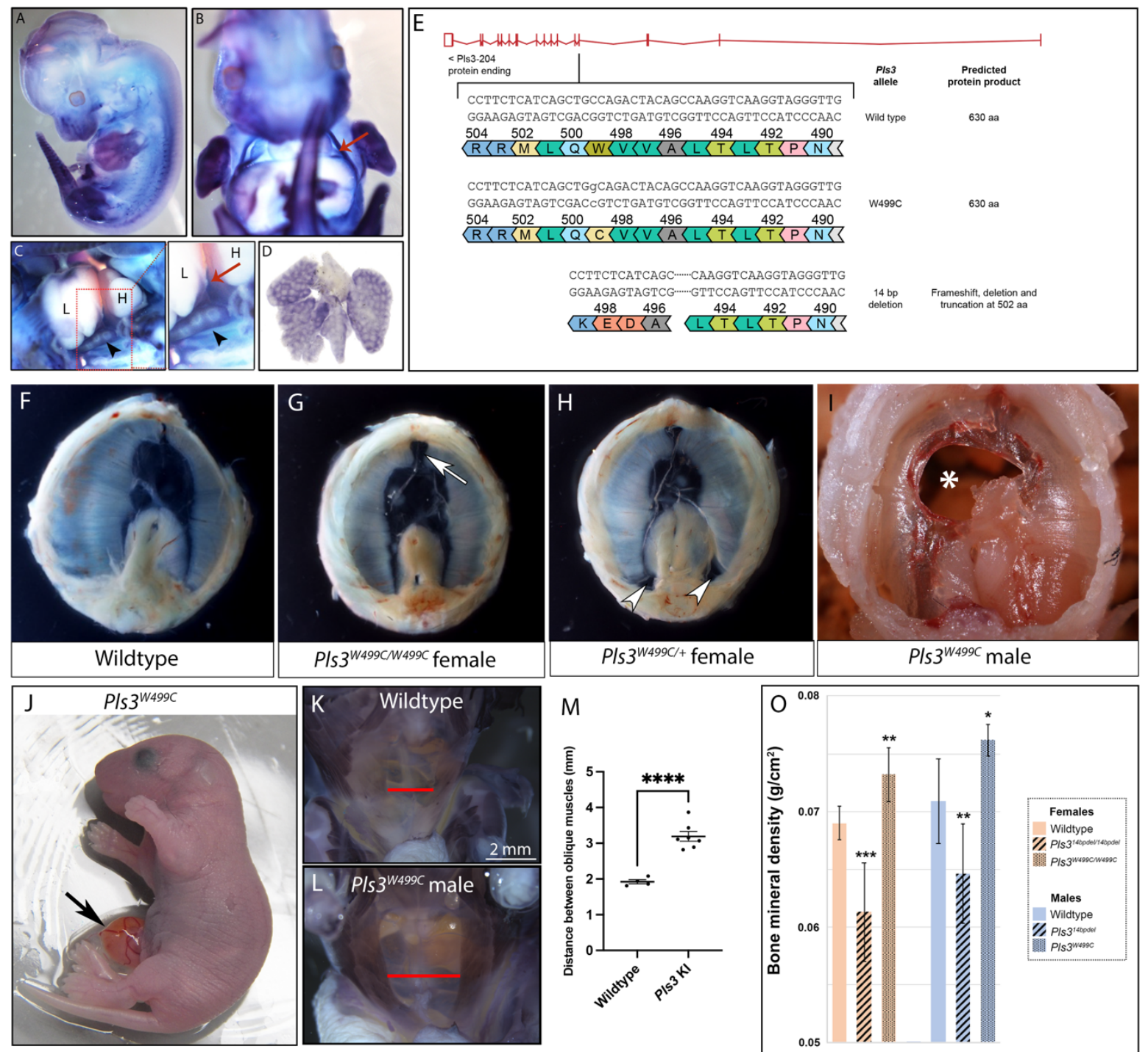

Females

Wildtype

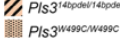

Males

Wildtype

V PIs $3^{\text {teposose }}$ 